\title{
Religionshistoriske og typologiske overvejelser over fænomenet askese
}

\author{
ANDERS KLOSTERGAARD PETERSEN
}

ENGLISH ABSTRACT: In the current article I raise the question of asceticism as a ubiquitous and multifarious phenomenon in human culture. Contrary to much traditional scholarship on asceticism within the history of religion that has focused almost exclusively on the phenomenon as confined to a Judaeo-Christian and Indian context, I point to the importance of bringing the later phenomena into dialogue with previous examples in tribal and archaic types of religion. In anthropology there has from an early period been a strong acknowledgement of the pervasiveness of ascetic practices not least in conjunction with ritual. Yet, this appreciation has never really been taken into consideration by scholars working on subsequent forms of asceticism. By means of genealogically typological reflections, I aim to develop a full scale understanding that will enable us to take the entire gamut of ascetic practices and phenomena into consideration. My ruminations rest on a biocultural evolutionary approach that allows me, on the one hand, to account for the pluriform nature of the phenomenon under scrutiny and, on the other hand, to place emphasis on the uniting features. From this perspective, two points of transition come to the fore of discussion. The first crucial transformation pertaining to asceticism took place at the time of the emergence of axial age thinking and practice at which period asceticism changed from being ritually to be ideologically determined. The second decisive change occurred at the transition from post-axial age types of religion to modernity when the element of privation disappeared. I develop my understanding of the specific nature of asceticism pertinent to the singular stages in the history of asceticism in the wake of thinkers such as Robert Bellah, Peter Sloterdijk and Pierre Hadot.

DANSK RESUME: Jeg præsenterer en generel typologi for fænomenet askese, som jeg samtidig udvikler inden for rammerne af en genealogisk model. Ambitionen er at præsentere en totalmodel, som er $i$ stand til at indfange askesen som et både alment og kontinuerligt kulturelt fænomen og som et element præget af betydelige transformati- 
oner og forskydninger i forhold til socio-kulturel kontekst. Det gør jeg dels i lyset af en overordnet biokulturevolutionær model (Donald og Bellah), dels på baggrund af tænkere som Peter Sloterdijk og Pierre Hadot, der netop har fremhævet det aksiale gennembrud som helt centralt for en forståelse af áskēsis som øvelse eller træning for sjælen. Artiklen er ikke mindst tænkt som et forsøg på at vise, hvordan man på den ene side kan og må drive en grandios form for kultur- og religionshistorie, og på den anden side må gøre det gennem stadig besindelse på de specifikke sammenhænge, i hvilke bestemte tekster og adfardsformer optræder.

KEYWORDS: askese; religionshistorie; religionsvidenskab; Peter Sloterdijk; aksetid; kulturel evolution

Il suit de là que l'ascéticisme n'est pas, comme on pourrait le croire, un fruit rare, exceptionel et presque anormal de la vie religieuse; c'en est, au contraire, un élément essentiel. Toute religion en contient au moins le germe, car il n'y en a pas où ne se recontre un système d'interdits. La seule différence qu'il y ait sous ce rapport entre les cultes, c'est que ce germe y est plus ou moins développé. ${ }^{1}$

\section{Mål og med}

Målet med denne artikel er at samle en række overvejelser med henblik på dels at drøfte fænomenet askese religionshistorisk, dels og i tæt sammenhæng med den religionshistoriske diskussion at udvikle en askesetypologi, som også er tænkt genealogisk. ${ }^{2}$ Mere specifikt har jeg fire intentioner. For det første og helt overordnet øn-

\footnotetext{
Durkheim 2007, 452. Citatet lyder i oversættelse: “Det følger, at askese ikke, som man skulle tro, er en sjælden frugt, usædvanlig og næsten anormal i forhold til det religiøse liv. Tværtimod er det et helt centralt element. Enhver religion indeholder i det mindste kernen, for der er ikke nogen religion, uden man finder et system af forbud. Den eneste forskel, der i den henseende er mellem de forskellige kulter, er kernens mere eller mindre udviklede karakter." Oversættelserne fra antikke og moderne sprog er mine egne; engelske citater er ikke oversat.

2 Jeg sammenstiller her refleksioner fra fem forelæsnings-, konference- og seminarsammenhænge, hvor jeg har drøftet forskellige facetter af askese, til et samlet billede. Det drejer sig om: "Fra punktuel til durativ askese: et kulturevolutionært perspektiv på askese" (Møde i Forskningsenheden for Religionshistorie, 24.09.2014); "Asceticism, Philosophy, and Religion and Their Interactions in Antiquity" (Forelæsning ved Max Weber Forschungskolleg, Universität Erfurt, 27.10.2014); “Instantiating a Possible Dialogue between Gavin Flood and Peter Sloterdijk: Incongruent or Convergent Concepts of Asceticism?" (International Research Symposium at the Department for the Study of Religion, University of Aarhus, 04.12.2014); "Askese og offer" (Askeseseminar i regi af Religionsvidenskabeligt Tidsskrift og DASR, 15.12.2014); "Asceticism from a Biocultural Evolutionary Perspective: Genealogically Typological Reflections on the Ubiquity and Multifariousness of Asceticism" (Forelæsning i forbindelse med 21st IAHR World Congress Erfurt 2015, 27.08.2015). Yderligere oplysninger om de enkelte seminarer og mine bidrag findes på min hjemmeside, se: http://pure.au.dk/portal/da/persons/anders-klostergaard-petersen(966b9914-b583-4e39-8af56c1684239191)/activities.html. Jeg er deltagerne i seminarerne tak skyldig for deres kritik, som har gjort
} 
sker jeg i modsætning til megen historie- og religionsvidenskabelig samt teologisk askeseforskning, der traditionelt har været optaget af fænomenet i en jødisk-kristen og indisk sammenhæng, og derfor har opfattet det som et post-500 f.v.t.-fænomen, at belyse sammenhængen til tidligere former for ritualiseret adfærd, som bør kategoriseres som askese. Inden for antropologien og den del af religionsvidenskaben, som har fokuseret på ritualer og deres betydning, har man traditionelt haft stor forståelse for asketiske praksisser i rituel sammenhæng (det gælder ikke mindst EvansPritchard og Victor Turner og den med dem forbundne tradition, ligesom det også indgår som et helt centralt element hos Durkheim selv og i den durkheimske tradition). Omvendt har man i klassisk 'historisk' askeseforskning udelukkende studeret fænomenet i tæt tilknytning til udviklingen af kristent munkevæsen (og enkelte efter min mening - ofte noget tvivlsomt postulerede jødiske forløbere som fx Qumran) og, subsidiært, i en indisk religionshistorisk kontekst.

Her ønsker jeg imidlertid ikke alene at forbinde den indiske med den jødiskkristne tradition ved at stille spørgsmålet om deres nærmere sammenhæng i et religionshistorisk perspektiv, men jeg vil yderligere se på forholdet mellem disse senere former for askese og den rituelle askese i før-aksiale religionstyper, ligesom jeg i forlængelse af den tyske kulturteoretiker og filosof Peter Sloterdijk vil pege på forbindelsen til moderne former for askese. Det sidste kræver imidlertid, at man ikke tænker askese i sammenhæng med et snævert religionsbegreb, men er åben over for at reflektere over det i en bredere religions- og kulturhistorisk ramme, hvor man også har blik for de væsentlige transformationer og forskydninger, som mange religioner undergår, når man når frem til det moderne. Det kræver et durkheimsk blik på verden, hvor religion tænkes ud fra et relationelt hellighedsbegreb reflekteret af et semantisk system (forstået både i relation til forestillinger, handlinger og institutioner) bestemt ved forbudte og adskilte ting, dvs. det hellige, og delt af en gruppe af mennesker (jf. Durkheims klassiske religionsdefinition). ${ }^{3}$

For det andet ønsker jeg at sammentænke to umiddelbart ikke forenelige askesebegreber. På den ene side er der den hævdvundne forestilling, hvor askese i overvejende grad tænkes som forsagelse i form af afkald. På den anden side er der i forlængelse af dels ordets græske betydning, áskēsis, dels af den bredere askeseforståelse, som man i sammenhæng med ordets græske grundbetydning finder hos Sloterdijk, en definition af askese som øvelse eller træning (se Lundager Jensen 2013). Mens den sidste betydning er forholdsvis let at identificere med Sloterdijks askesedefinition, vælger jeg at lade den første og forskningshistorisk dominerende opfattelse repræsentere af Gavin Flood, som har skrevet en forbilledlig klar fremstilling af askese som

det muligt at videreudvikle min forståelse. En særlig tak til min kollega Hans Jørgen Lundager Jensen som med- og modspiller og til Tove Tybjerg for konstruktiv kritik til artiklen i en tidligere skikkelse.

Durkheim 2007, 95f: “Vi når således frem til følgende definition: en religion er et sammenhængende system af trosforestillinger (croyances) og adfærdsformer, som forholder sig til hellige fænomener, dvs. fænomener som er skilt ud og tabuiserede (interdites), og som forener det til samme moralske fællesskab, kaldet en kirke, bestående af dem, som slutter sig til den." 
afkald og forsagelse, men netop ikke privation forstået som en berøvelse, man af andre udsættes for på sin krop. ${ }^{4}$ Det kan være indgreb på kønsorganer som fx kvindelig og mandlig omskærelse, bortfjernelse af hår, tænder eller lignende. Jeg føjer dog et afgørende element til Floods og andre forskeres drøftelse af askese som afkald, idet jeg opfatter privation som et yderligere meget væsentligt aspekt. Jeg pointerer også, at afkald og privation må tænkes som kultur- og religionshistorisk selvstændige, men samtidig forbundne begreber. Deri ligger en vigtig pointe, som yderligere sætter mig i stand til at forbinde aksiale, postaksiale og moderne former for askese med ældre former. Jeg skal i denne sammenhæng også præcisere, at når jeg anvender begreberne kultur- og religionshistorie synonymt, om end med forskellig betoning, er det velovervejet. Frem til slutningen af det 18. århundrede og et godt stykke ind i det 19. århundrede var religion og kultur sammenfaldende størrelser. Hvad vi i dag opfatter som hinanden uafhængige sfærer, politik, økonomi, underholdning, etc., var og er fremdeles i stadig betydelige dele af verden en uomgængelig del af, hvad vi fra et tredjeordensperspektiv må betegne religion. Naturligvis, havde jeg nær sagt, er der forskel på toilet- og tempelbesøg, men selv forrettelse af nødtørft var i fx klassiske religioner omgærdet med en række renhedsregler, som gjorde det til en del af religionen. Man kan også blot tænke på teater i en græsk sammenhæng, som fx i Athen var snævert knyttet til afholdelsen af de panathenæiske lege, der igen var indlejret i den religiøse kult. Det er med andre ord et modernitetstræk, at man overhovedet er kommet til at kunne tænke religion som selvstændig sfære i forhold til en række andre og derfor uafhængige domæner.

Formålet med iscenesættelsen af en samtale mellem Sloterdijks og Floods askeseforståelser er at bane vej for en opfattelse, der rummer begge de nævnte elementer i begrebsdefinitionen, askese som træning og som forsagelse. Jeg ser dette synspunkt som helt afgørende for forståelse af de former for askese, der udvikler sig ikke alene i sammenhæng med det aksiale gennembrud ved overgangen fra det sjette til det femte århundrede f.v.t., ${ }^{5}$ men også i den videre udvikling fra postaksiale til moderne askeseformer. I forbindelse med sammenstillingen af askese som forsagelse og som træning bruger jeg Pierre Hadots tanke om antik græsk-romersk filosofi som en livsvej, une manière de vivre. Her finder jeg det tredje punkt, som sætter mig i stand til at iscenesætte en egentlig dialog mellem Sloterdijks og Floods umiddelbart uforenelige askeseopfattelser. Det kræver dog, at man lader Floods opfattelse bestemme af den sloterdijkske, fordi Flood selv holder fast i et meget traditionelt og snævert askesebegreb, der for det første tænkes i tæt sammenhæng med et stærkt traditionsbegreb (askese som kropslig virkeliggørelse af bestemte religiøse traditioner), og for det andet snævert knyttes til skriftreligionerne, altså netop de religioner, som først vokser frem fra og med den aksiale vending.

4 Denne forståelse er også det bærende synspunkt i den forskningshistorisk centrale antologi Asceticism redigeret af Vincent Wimbush og Richard Valantasis, som er blevet et standardreferenceværk i moderne askeseforskning

5 Se hertil Hans Jørgen Lundager Jensens og mine artikler i RvT 2013. 
For det tredje ønsker jeg at rette fokus mod en bestemt transformationsbevægelse, som meget illustrativt tjener til at understrege forskellen mellem forskellige typer af askese, og som jeg betegner som overgangen fra det transitive til det refleksive offer med martyriet som den mest excessive form for selvoffer: jeg'et, der totaliter et aliter giver eller ofrer sig i selvimmolation. ${ }^{6}$ De to offertyper er ikke alene et oplysende, men også markant udtryk for den overgang i askesebrug, som jeg stiller skarpt på under det første punkt, og som samtidig gør det muligt for mig at indføre den omtalte sondring mellem askese som forsagelse og som privation. Derved kommer det tredje punkt ikke alene til at tjene som nærmere illustration af det forhold, jeg fokuserer på under punkt 1, men også som yderligere klargøring af forskellen mellem den rituelle askese og den form for askese, hvor hele livet forstås som en asketisk vej mod den sande form for væren, altså en ideologisk diskursiveret bestemt form for askese. $^{7}$

For det fjerde ønsker jeg delvist i forlængelse af Oliver Freiberger at gøre studiet af askese til et komparativt projekt. Det har der været for lidt af i hidtidig askeseforskning. Freiberger har som en af de få været optaget af at påpege sammenhænge mellem indisk og kristen askese; men også han kommer til kort i forhold til at tænke det komparative mere grandiost, fordi han indskrænker det til mere komplekse former for religiøsitet. Det har været meget småt med studier, som er gået på tværs af kulturer og forskellige historiske udviklingstrin. Den specifikt ritualindlejrede askese er fx aldrig blevet undersøgt i sammenhæng med senere former for kristen og hinduistisk askese, ligesom man savner studier, som fokuserer på forholdet mellem mere ideologisk definerede former for askese i aksiale, postaksiale og moderne kulturer og rituelt permanente typer for askese inden for tribale eller indfødte folks religioner/kulturer. ${ }^{8}$

Af de fire punkter forholder de tre sig til det overordnede første, nemlig forsøget på at udarbejde en samlet genealogisk funderet religions- og kulturtypologi for askesen som fænomen. Inden jeg går over til drøftelsen af de fire punkter, vil jeg imidlertid først præsentere den typologi, som danner grundlag for min diskussion af enkeltpunkterne.

\footnotetext{
Det ligger meget i forlængelse af et aktuelt trilogiprojekt, hvor jeg netop arbejder med bevægelsen fra det transitive til det refleksive offer, og forfægter det synspunkt, at det sidste skal ses som helt grundlæggende for det aksiale nybrud. Se også min 2011a-artikel.

7 Det er den askesetype, Peter Brown i sin forskningshistorisk betydningsfulde 1988-monografi beskæftigede sig med.

8 Jeg bruger her kultur og religion synonymt, da jeg ikke mener, man i denne sammenhæng kan operere med en egentlig skelnen mellem kultur og religion, eftersom de to er sammenfaldende størrelser. Selvfølgelig kan man sondre mellem forskellige grader af religiøsitet, men pointen er netop, at der er tale om grader på et kontinuum og ikke kategoriale forskelle mellem forskellige livssfærer. Det er da også derfor, der er en lang tradition for i antik religionshistorisk sammenhæng at differentiere mellem det hellige og det profane (egtl. 'det der ligger hinsides templet'), men netop ikke sekulare. Der er således tale om forskellige grader af hellighed, hvor templets inderste udgør det hellige par excellence, mens graden af hellighed aftager jo fjernere, man kommer fra templet.
} 
Tanken med typologien er dels at påpege sammenhængen mellem forskellige askeseformer, dels at understrege forskellene mellem de forskellige askesetyper knyttet til deres evolutionshistoriske kontekst. Typologien har derfor ikke alene synkron karakter, men er også tænkt genealogisk og derfor diakront. Jeg skal senere mere udførligt vende tilbage til dette punkt. Jeg vil dog godt allerede her forudskikke en mulig kritik. Jeg maler i denne artikel askesens historie med en meget bred pensel, der ikke levner megen plads til kulturspecifikke og socialhistoriske nuancer. Det er et bevidst valg, fordi jeg her primært ønsker at lægge nogle mere principielle typologisk-genealogiske overvejelser frem til diskussion. Finder andre dem lige så meningsfulde, som jeg aktuelt gør, er der imidlertid et betydeligt potentiale for et fremtidigt stort komparativt askeseprojekt i en kulturevolutionær sammenhæng.

Og så en ting til. Det gælder for en hvilken som helst typologi, også den genealogisk funderede, at den ikke står og falder med direkte korrespondance til enkeltmanifestationer. For det første er der typologisk-genealogisk tale om et kontinuum, hvor det genealogiske alene skal sammenfatte overordnede bevægelsesmønstre i en given epoke og på et bestemt sted. Ingen påstår, at overordnede kulturelle forskydninger kan tidsfæstes meget præcist. For det andet kan en typologi aldrig falsificeres af afvigende enkeltmanifestationer, eftersom den netop er tænkt generelt som paradigmatisk for overordnede mønstre. Først i det øjeblik, hvor typologien afviger fra en mere omfattende række kulturelle enkeltmanifestationer, må man naturligvis tage den op til fornyet overvejelse og revision eller eventuelt forkastelse. Som allerede Max Weber klart redegjorde for, og som det siden af Smith i forlængelse af Korzybski (oprindeligt 1931) er blevet fyndordsagtigt formuleret, er der forskel på model og virkelighed eller kort og territorium (Weber 1920, 536-42; Kozybski 2000, 750f; Smith 1978, 309).

\section{En askesetypologi}

Som allerede antydet finder jeg det problematisk at reducere askese til et aksialt og postaksialt fænomen. ${ }^{9}$ I den antropologiske tradition og inden for den del af religionsvidenskaben, der i særlig grad har været optaget af religion i tribale sammenhænge, har man altid været interesseret i forskellige askeseformer i den rituelle kontekst, hvad enten det drejede sig om faste, seksuel afholdenhed, afkald på søvn, eller mere ekstreme former for legemlig privation som fx barbering af hovedhår, omskærelse og tandberøvelse. Denne type askese kan dog ikke begrænses til alene et spørgsmål om episodisk rituelle former i forbindelse med fx initiation og kollektive

Det er netop karakteristisk for det vel nok mest centrale samleværk i moderne askeseforskning, Wimbush \& Valantasis 1995, at man overhovedet ikke finder henvisninger til Durkheim, Victor Turner, Mary Douglas eller den øvrige antropologiske tradition, ligesom askese i en tribal sammenhæng end ikke optræder i sagregisteret. 
kriseritualers præliminale fase. Vi finder den også som et mere kontinuerligt fænomen som i fx shamanisme.

Relevansen af en sådan sondring mellem mere episodiske og konstante former for askese optræder imidlertid også, når man historisk bevæger sig frem til aksiale religionstyper. Også her optræder askese såvel i en mere efemerisk som i en vedvarende form; men i modsætning til de asketiske fænomener, der optræder i den tribale og arkaiske religionskontekst, ${ }^{10}$ kan man konstatere, at den permanente askese har løsrevet sig fra den specifikt rituelle kontekst, så askesen har fået en mere ideologisk bestemt karakter. Askesen er på denne måde blevet del af en hverdagspraksis:

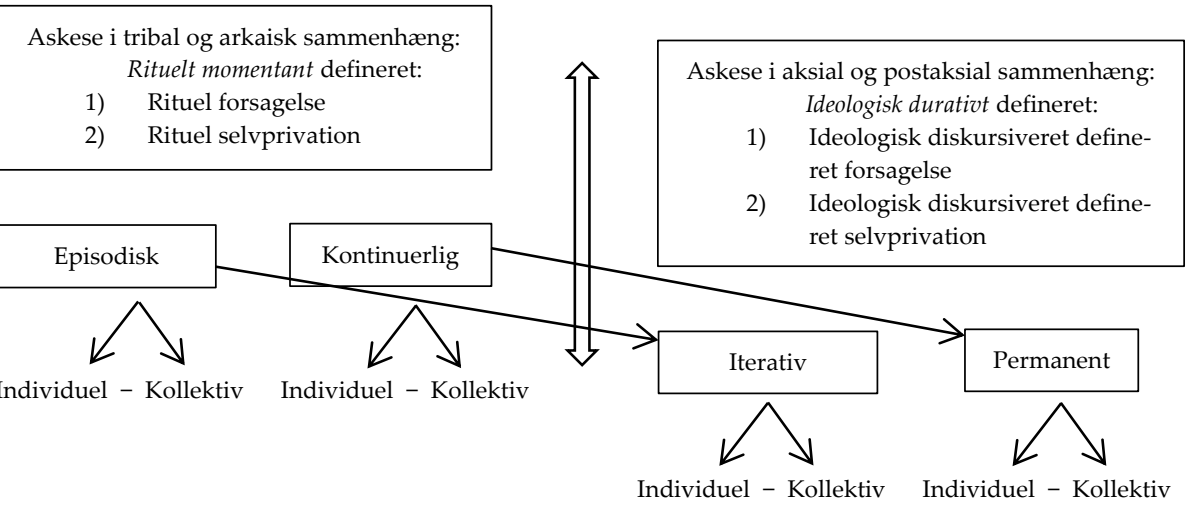

Pointen i den grafiske oversigt er på en og samme tid at fremhæve forskelle og understrege ligheder mellem askese i en tribal og arkaisk sammenhæng over for den aksiale og postaksiale kontekst. Det ville være rimeligt også at understrege forskellen mellem aksial og postaksial askese, hvor den sidste bedst lader sig forstå som en sammenstilling af den aksiale og arkaiske religionsform, hvorved den sidste stærkt metaforiseres $\mathrm{i}$ forhold til den oprindelige arkaiske religionstype. Man kan fx blot tænke på kristne kirkebygninger, gennem hvilke de arkaiske religioners tempelarkitektur fra et tidligt tidspunkt reintroduceres i en aksial ideologisk defineret sammenhæng. Noget tilsvarende gør sig gældende i fx nadver- og præsteforståelse; men dette i øvrigt interessante delemne må jeg her af pladsgrunde give afkald på at drøfte. ${ }^{11}$ Et væsentligt element vil jeg dog betone. Det gælder i min argumentation her som for den kulturelle evolution generelt: "Nothing is ever lost," der kan stå som fortættet udtryk for den grundlæggende tanke i Robert Bellahs kulturopfattelse (se særligt Bellah 2005, 72; 2011a, 267; 2011b; jf. Donald 2006, 9.19f).

10 Jeg vil dog godt understrege, at jeg for det første med sammenstillingen af det tribale og arkaiske ikke hævder, at de to er uden forskelle i henseende til askese, ligesom jeg heller ikke argumenterer for, at der inden for de to kan findes forskellige mere eller mindre komplekse former for askese. I denne sammenhæng er det imidlertid de overordnede typologiske ligheder og forskelle, jeg fokuserer på.

11 Denne ikonografiske fremstillings iøjnefaldende mangel er selvsagt den manglende sondring mellem henholdsvis det tribale og det arkaiske og det aksiale og postaksiale; men pointen her er at fokusere på det, der forbinder tribal med arkaisk og aksial med postaksial askese. 
Ganske som i den specifikt biologiske evolution gælder det også for den kulturelle evolution, at lag føjer sig til lag, og danner stadigt mere komplekse kulturformer. Som mennesket fortsat bærer rundt på rygsøjlen som reminiscens af sin evolutionære fortid som hvirveldyr, rummer kulturudvikling også lag fra tidligere evolutionære sammenhænge. Ja, grundlæggende vil jeg gå så vidt som til at hævde, at der kun er én evolution, og den er af biologisk karakter (se Klostergaard Petersen 2015a og b). Hvad vi traditionelt betegner den kulturelle evolution, er helt igennem del af den biologiske evolution, men henviser til den mest komplekse form på det udviklingskontinuum, som har sat homo sapiens sapiens i stand til i sin omgang med biologien at benytte omverdenen, hvorved også biologien forandres. Evnen til ekstern hukommelseslagring som fx i skrift øver derved også indflydelse på menneskets biologi. Men tilbage til den (bio)kulturelle evolution - og jeg vil godt nu understrege, at når jeg fremover taler om kulturevolution, forstår jeg det som biokulturevolution. Samtidig med at elementer forskydes og forandres, er der nemlig også en betydelig grad af gentagelse. Således genfindes den tribale og arkaiske modstilling mellem efemeriske og permanente former for askese i en aksial og postaksial sammenhæng som en forskel mellem momentane og varige askesetyper; men der er netop tale om en niveauforskydning. Askesen er ikke længere specifikt bundet til en rituel kontekst, men befinder sig i højere grad inden for rammerne af en ideologisk defineret sammenhæng. Det er, hvad Pierre Hadot betegner en livsvej.

Det samme gælder fx i forhold til forskydningen mellem den aksiale og postaksiale askese over for den moderne, som jeg i grove træk har forsøgt at fremhæve i nedenstående graf - betydningen af grosso modo skal her virkelig tages for pålydende, da man selvsagt kan pege på en række fænomener, der komplicerer billedet; men pointen er netop, at der er tale om hovedtræk, jf. min tidligere pointe om typologiens epistemologiske status som model og ikke empirirefleksion. I moderne former for askese forsvinder privationsaspektet imidlertid, ligesom askesen i den rituelt definerede sammenhæng afløses af en rent ideologisk bestemt form for askese.

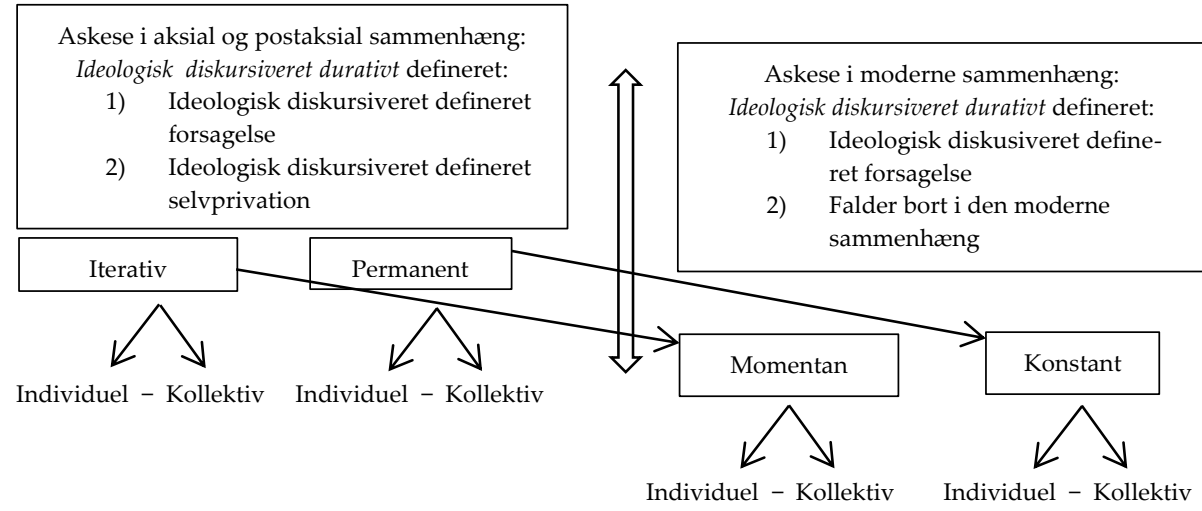




\section{En kulturevolutionær drøftelse af askese}

Hvor det meste af den klassiske og moderne askeseforskning har været optaget af askese som et fænomen, der hører verdensreligionerne til, og her primært de indiske og jødisk-kristne og delvist islam, har man ikke i fornøden grad fået påpeget forbindelsen til tidligere askeseformer. Man skal imidlertid ikke have arbejdet længe med antropologisk eller klassisk religionsvidenskabelig ritualforskning for at konstatere, at vi i høj grad finder askese i skikkelse af forskellige former for afkald og selvprivation i rituelle sammenhænge, hvad enten det drejer sig om tribale eller arkaiske religionsformer. Allerede Emile Durkheim gjorde i Les Formes élémentaires de la vie religieuse opmærksom på sammenhængen mellem asketiske praksisser og det, han betegnede den negative kult. Ja, faktisk var Durkheim den første til at understrege forbindelsen mellem askese og ritualdeltagerens rituelle bevægelse fra den profane til den hellige sfære. Han talte i den sammenhæng om, hvordan de to sfærer (les deux mondes) ikke alene opfattes som adskilte, men også som fjendtlige og misundelige rivaler over for hinanden. Der er tale om et fjendskab (antagonisme) mellem dem $(2007,86)$ : “Eftersom man kun fuldstændigt kan tilhøre den ene under forudsætning af, at man helt har forladt den anden, opfordres mennesket til aldeles at trække sig fra det profane for at føre et eksklusivt religiøst liv." Durkheim nævner i den sammenhæng både munkevæsen og mystisk askese, ligesom han fremhæver det religiøse selvmord som askesens logiske slutpunkt: "eftersom den eneste måde fuldstændigt at fly det profane liv er aldeles at undgå livet" (ibid.). Durkheim betoner også askesens almenreligiøse karakter. Den er et universelt religionshistorisk fænomen:

Det følger, at askesen ikke, som man skulle tro, er en sjælden frugt, undtagelsesvis og næsten anormal i det religiøse liv. Helt modsat er den et væsentligt element. Enhver religion indeholder i det mindste kimen, for man finder ikke et system uden forbud. Den eneste forskel, som består mellem de forskellige kultur, det er om kimen er mere eller mindre udviklet (p. 452).

Durkheim drøfter ikke mindst askesen i sammenhæng med den negative kult og dens funktion. Her hedder det i lighed med den tidligere pointe: "I sandhed i kraft af den barriere, som adskiller det hellige fra det profane, kan mennesket ikke komme i tæt forbindelse med hellige ting, medmindre det skræller, hvad der er af profant, af hos sig selv. Det kan kun leve et religiøst liv en smule intenst, når det begynder at trække sig mere eller mindre tilbage fra det verdslige live (de la vie temporelle)" ( $\mathrm{p}$. 448). Ved at berede overgangen til den positive kult finder den negative sin betydning:

Det menneske, som har udsat sig for de foreskrevne forbud, er ikke det samme, som det var forud. Tidligere var det en almindelig væren, der netop derfor måtte holde sig på afstand af de religiøse kræfter. Derefter er det mere på lige fod med dem, fordi det har nærmet sig det hellige i kraft alene af at have fjernet sig fra det profane. Det har renset 
og helliget sig og alene i kraft af det løsrevet sig fra lave og trivielle ting, som tidligere tyngede det (p. 448f.).

Derved får Durkheim sagt noget centralt om askesens bundethed til den præliminale fase eller separationsfasen, som er Turners andet udtryk for ritualets indledende stade (se fx Turner 1969, 103). Forudsætningen for at kunne nærme sig den anden verden og dens aktører er en kategorial adskillelse fra denne verden. Det sker typisk gennem brug af rituel symbolisering, som markerer afskeden med de elementer, der regnes for centrale for tilhørsforholdet til denne verden som fx seksuel differentiering, søvn, klæder, mad og drikke. Durkheim siger det klart i forlængelse af Huberts og Mauss' klassiske offerstudium: "Man kan anvende salvninger, lutringer og velsignelser til alt dette, grundlæggende positive handlinger; men man kan nå samme resultat gennem faster, vigilier, gennem retræte og stilhed, det vil sige gennem rituelle former for afholdenhed, som ikke er andet end bestemte forbud omsat i handlen" (p. 449; med behørig reference til Hubert og Mauss 1899, 22-25).

Afskeden med livsopretholdende elementer er et afgørende aspekt; men det er imidlertid ikke tilstrækkeligt til at forklare det volds- og privationselement, som også indgår som et centralt led i tribale og arkaisk rituelle separationsfaser. På det punkt kommer Durkheim i min forståelse til kort, fordi han ikke i tilstrækkelig grad skelner mellem privations- og afkaldsaspektet, men opfatter dem som et kontinuum. ${ }^{12}$ Deri kan han have ret; men det er under den forudsætning, at man gør sig klart, at det alene er retrospektivt fra et kulturevolutionært perspektiv, der er tale om et kontinuum, hvilket Durkheim ikke tydeliggør. Det er imidlertid væsentligt at begribe privationsaspektet selvstændigt, hvis man skal forstå den senere udvikling, når vi dels når frem til aksiale og postaksiale askeseformer, dels til de moderne.

Ud over overgangen til en anden verden, hvor man berøvet denne verdens velsignelser beredes til at møde den anden verdens aktører, hører også en rituel markering af magtforholdet mellem denne verdens og den anden verdens aktører. ${ }^{13}$ I sidste

12 Det fremgår fx af Durkheim 2007, 451: "Den rene asket er et menneske, som hæver sig over andre mennesker og som opnår en særlig hellighed gennem faster, vigilier, retræte og stilhed, i et ord gennem privationer mere end gennem den positive fromheds handlinger (gaver, ofre, bønner, etc.)." Jf. også p. 452.

13 Jeg vil godt understrege, at når jeg her taler om denne verden til forskel fra den anden verden, indebærer det ikke en påstand om, at tribale og arkaiske religioner alene skulle operere med en tostrenget verden. Inden for antropologi og socialvidenskab plejer man at tale om den 'ontologiske vending', som gerne tidfæstes til en gang i løbet af det sidste tiår, og som netop forudsætter en langt større forståelse for dels eksistensen af flydende ontologier, dels tilstedeværelsen af flere verdener i tribale sammenhænge (samme argument gælder eo ipso i forhold til arkaiske kulturer). Jeg er således helt på det rene med 'perspektivisme'-diskussionen, dvs. eksistensen af flere perspektiver også i tribale kulturer, sådan som jeg også selv i forlængelse af Paul Veyne har bragt det i anvendelse på arkaiske kulturer (se fx Petersen 2005, 549-55); men det ændrer blot ikke ved, at man analytisk må gøre en kategorial skelnen gældende mellem denne og den anden verden, uanset hvor mange verdener den anden verden så i øvrigt tænkes at udgøre, og uafhængigt af hvor meget den anden verden hævdes at gribe ind i denne verden, eftersom den anden verdens indgriben i denne verden vil have en kontraintuitiv karakter. For perspektivisme-drøftelsen og den mere grundlæggende diskussion af ontologiers flydende karakter, se fx Descola 1996 og 2005 samt Viveiros 1998. Halbmayer 2012 udgør en udmærket oversigtsartikel, hvor han gennemgår det meste af den relevante antropologiske litteratur. 
instans skylder man sit liv den anden verden, som er forudsætningen for den givne verdens eksistens. Det indebærer en asymmetrisk relation mellem denne verdens og den anden verdens aktører, hvor man - rituelt markeret gennem privation - anerkender sin underlegenhed og status som kontraktuel tjener i forhold til den anden verdens herrer. Det er dette forhold, som rituelt gennemspilles i separationsfasens voldsaspekt. Det eneste, man har at betale tilbage med for alt, hvad man har modtaget, er det liv, man har fået. Der er ikke tale om et do ut des-forhold, men snarere en do quia dedisti-relation. Principielt burde man betale tilbage med hele sit liv (det kommer vi til, når vi når frem til det refleksive offer i den aksiale sammenhæng); men da det selvsagt ville føre til livsophør og dermed også ødelæggelse af den kontraktuelle relation, sker anerkendelsen i stedet som en indeksikal metonymisk udveksling, ${ }^{14}$ hvor ritualdeltageren kan nøjes med en pars pro toto-betaling gennem afbarbering, tandberøvelse, omskærelse, etc. Der er dog ingen tvivl om, at de forskellige privationselementer indeksikalt betegner en lille død, som i meget bogstavelig forstand slår magtforholdet og den kontraktuelle relation mellem gavegiver og modtager fast: "Hvad har du, som du ikke har fået givet!" Min sondring mellem forsagelses- og privationsaspektet kan også formuleres på en lidt anden måde. I askesen forstået som forsagelse handler mennesket selv. Det kan godt være, at det underkaster sig en række normer for, hvordan det idealiter bør agere; men det er ritualsubjektet selv, som beslutter sig for fx i en kortere eller længere periode at faste. Det er anderledes i forhold til privationsdimensionen. Her er det andre, som på vegne af den guddommelige verden handler med en. Man er med andre ord subjekt i den asketiske forsagelse, mens man i den asketiske privation er transformeret til objekt.

Hvad der gælder individuelt og episodisk, kan i en mere kompleks form for tribal sammenhæng udvides, så det også får social betydning i en kontinuerlig kollektiv forbindelse. Basalt er det samme metonymiske relation, der er på spil. Man kan som samfund vælge at udskille enkeltindivider, ligesom man kan udsondre en gruppe, der på vegne af samfundet (som pars pro toto) tjener til at stadfæste og opretholde forbindelsen til den anden verden og dens aktører. Separationsfasen bliver på denne måde forskudt til en kontinuerlig form for separation, som gælder bestemte individer eller et kollektiv, der på vegne af samfundet - indeksikalt markeret gennem udsondring - konfirmerer den kontraktuelle relation mellem de to verdener, denne og den anden verden. Når jeg taler om en udsondring som karakteristisk for en mere kompleks samfundstype, er argumentet, at det kræver en livsform, hvor man kan tillade en større eller mindre gruppe af mennesker at ernære sig på grundlag af det, den større gruppe er i stand til at udvinde af naturens ressourcer. Den større gruppe skal ikke alene være i stand til at opretholde eget liv, men også kunne brødføde den

Jeg bygger her på Roy Rappaports peirciansk semiotisk funderede ritualteori, som jeg første gang introducerede i en dansk sammenhæng i min 1996-artikel, og som jeg siden i forhold til skelnen og værdsættelsen af indeksikale, ikoniske og symbolske elementer i et hvilket som helst ritual har lagt afgørende vægt på. Se fx mine artikler 2004, 2011b, 2013e. 
gruppe, man har valgt at tildele den kontinuerligt separative funktion som mediatorer mellem denne og den anden verden.

Dermed har jeg mere specifikt bevæget mig over til det kulturevolutionære spørgsmål. Da denne tænkning fortsat nyder betydelig akademisk modstand, vil jeg godt understrege over for dem, som fortsat måtte opponere mod et sådant perspektiv, at jeg ikke drøfter spørgsmålet i relation til det sande eller gode, men alene i forhold til det skønne. Jeg tager ikke stilling til, om en type samfund er mere sand eller bedre end en anden. Jeg er alene interesseret i spørgsmålet i relation til det æstetiske domæne, hvor det helt afgørende punkt vedrører graden af kulturel og social kompleksitet. Det forekommer mig enfoldigt, grænsende til ideologisk selvfornægtelse, og uvidenskabeligt ikke at anerkende, at der i henseende til kompleksitet er en verden til forskel på New York i dag og et stenaldersamfund for 5000 år siden. Det samme gælder kunst. Uanset hvor komplekse tribale samfunds kunstfrembringelser måtte være (og de kan være utrolig komplekse), ${ }^{15}$ kommer de ikke i henseende til kompleksitet i nærheden af moderne vestlige former for kunst. Det gælder også moderne vestlige kunsttraditioner som fx COBRA, der hentede betydelig inspiration i tribal ikonografi. Når COBRA netop ikke er tribal, hænger det sammen med, at den som bevægelse samtidig lægger sig i forlængelse af og bygger oven på en vesterlandsk flere hundrede år gammel kunsttradition, som den ikke kan være foruden. Derfor er den mere kompleks. Og lad mig så hertil føje et yderligere forhold. Det er efter min bedste overbevisning en misforståelse, når kolleger under kategorien tribal og indfødte folks religioner sammenblander mere autentisk tribale religioner med moderne tribale religioner, som befinder sig i en socio-kulturel kontekst, hvor de har været udsat for intens modernitetspåvirkning. Skal man i dag tale om tribale religioner eller kulturer, bør begrebet kun anvendes med henblik på den af den moderne verden fortrinsvis uberørte indfødte folks kulturer - og ja, de findes stadig som i fx Brasilien og på Papua Nyguinea. I stedet foreslår jeg, at man om hopi-indianere, chumash-indianerne og lignende anvender en anden nomenklartur, som gør det terminologisk klart, at vi taler om to forskellige, men også distinkte fænomener. ${ }^{16}$ Alt

15 I og for sig kan man drøfte, om man overhovedet skal betegne det kunst, eftersom kunst sensu stricto forudsætter en lang evolutionær udvikling, hvor en særlig form for oprindelig religiøs ikonografi udvikler sig til en selvstændig ikonografi løsrevet den oprindelige religiøse ramme. Det sker i første omgang med portræt- og siden landskabsmaleriet, men så har vi også bevæget os frem til det 16. århundredes vesterlandske kontekst og derved den tidligste form for modernitet forstået som selvstændiggørelsen af forskellige og fra hinanden uafhængige kulturelle sektorer, der komplementeres af en tilsvarende selvstændiggørelsesproces inden for det sociale felt.

16 Når det så er sagt, har jeg også taget ved lære af Armin Geertz, som ved flere lejligheder har pointeret, at tanken om 'genuint' tribale religioner er en saga blot. De findes ganske enkelt ikke, for selv, hvad der tager sig ud som mere 'oprindelige' religioner eller kulturer, viser sig ofte at have undergået betydelige forandringsprocesser, hvor de fx er gået fra agerbrug tilbage til et jæger-samfund stade, hvad der selvsagt komplicerer billedet yderligere. Dertil kommer, at flere af disse forandringer ofte er afstedkommet af netop påvirkning fra andre, stærkere kulturer, som har trængt tribale kulturer yderligere i defensiven, både geografisk og kulturelt, ved fx at pånøde dem til at vende tilbage til tidligere udviklingstrins mindre komplekse form for samfund og kultur. Jeg er i denne som i så mange andre sammenhænge Armin Geertz tak skyldig for belæring og horisontudvidelse. 
andet fører til forplumring, for Bellahs teorier om tribalkultur og religion kan i sagens natur ikke bringes i anvendelse på dem, der har været udsat for modernitetens påvirkning. Man må hellere se på dem som et blandingsfænomen mellem en række forskellige kulturevolutionære stadier, hvilket, parentetisk bemærket, også gør det lettere at tage den kritik af tribalbegrebet rettet mod Bellah fra et politisk korrekt perspektiv ad notam. Men hvad har det med askesen at gøre? Rigtig meget.

Min pointe er, at de to aspekter, jeg her har fremhævet som afgørende for tribale askeseformer, nemlig separationselementet og forsagelsesdimensionen, lever videre $\mathrm{i}$ senere askeseformer. De to dimensioner udgør konstanten, som afhængig af den specifikke kulturevolutionære kontekst får en lang række varierende manifestationer, hvor de senere bygger oven på og videreudvikler de tidligere. For at undgå misforståelser vil jeg dog godt pointere, at jeg ikke opfatter de specifikt kulturelle udtryk som varianter. Jeg mener, der er tale om grundlæggende meget forskellige fænomener afhængigt af, om man ser på askese i en tribal, en arkaisk, en aksial, postaksial eller moderne sammenhæng. Når det så er sagt, vil jeg imidlertid også betone kontinuiteten, som alene fremgår af det forhold, at jeg er i stand til at indfange de forskellige belyste fænomener under et samlebegreb dækkende al askese.

Denne kontinuitet gør det nærliggende at overveje, i hvilken udstrækning der er tale om et mere grundlæggende kognitivt fænomen af almenmenneskelig karakter. Det spørgsmål forfølger jeg i en række kommende publikationer, men vælger her af pladsmæssige hensyn til at begrænse mig til det kulturevolutionære spørgsmål løsrevet fra det specifikt biologiske og kognitionsteoretiske. ${ }^{17}$ Endelig vil jeg forudskikke yderligere en indvending knyttet til min tale om udvikling og evolutionær kompleksitet. Der eksisterer selvsagt også forskellige former for asketiske reformationer i den forstand, at man på senere udviklingstrin bevidst kan vælge en tilbagevenden til forenkling; men det er analogt til mit eksempel fra billedkunsten. Selv når protestantisk lavkirkelige bevægelser som $\mathrm{fx}$ menonitter og herrnhuter reintroducerer asketisk forenklende livspraksisser, gør de det i modsætning til konkurrerende livsformer, som de gennem deres afstandtagen fra dem derved også bygger ovenpå. Der er aldrig tale om en egentlig ren recours du temp perdu.

17 Jeg har i anden sammenhæng argumenteret for, at sondringen mellem biologisk og kulturel dybest set er kunstig, fordi vi som mennesker, selv når vi er allermest finkulturelle som fx under opførelsen af en Wagner-opera i Bayreuth, samtidig er biologiske totaliter et aliter. Det gør ikke skelnen mellem biologi og kultur overflødig; men brugen af sondringen forudsætter, at man er sig bevidst, at der alene er tale om et biologisk kontinuum, som selv de mest komplekse former for kultur befinder sig indenfor. Dertil kommer, at hvis vi med kultur mener evnen til brug af symbolisering, kommer også enkelte dyrearter som fx delfiner, chimpanser og bonoboer tæt på protokulturel beherskelse. Det samme gælder i forhold til en kulturopfattelse forstået som evnen til at lyve (til forskel fra bedrag), som de samme dyrearter kommer meget tæt på. Hvis man omvendt i forlængelse af fx Merlin Donald i overvejende grad forstår kultur som evnen til eksternalisering af symbolsk hukommelse (den specifikt teoretiske kultur hos Donald), er det imidlertid også vigtigt at pointere, at det kun kan finde sted under forudsætning af en biologi, som denne eksternalisering også er en integreret del af. Se mine 2015a og b-artikler samt ikke mindst Merlin Donald 2001 for en mere grundig og principiel drøftelse. Jeg er Donald stor tak skyldig for mange samtaler om dette emne i løbet af de sidste par år, ligesom jeg i henseende til inspiration står i en betydelig taknemmelighedsgæld til ham. 


\section{Fra tribal og arkaisk til aksial askese}

Jeg har allerede berørt forskellen mellem den henholdsvis tribale og arkaiske form for askese over for den aksiale, postaksiale og moderne. Det drejer sig først og fremmest om forskydningen fra en rituel til en ideologisk defineret kontekst for askesen. Selvsagt genfindes rituelle askeseformer også i den aksiale, postaksiale og moderne sammenhæng; men pointen er, at de i vid udstrækning kommer til at vige for ideologisk definerede askesetyper. Man kan diskutere, hvornår man præcist skal tidsfæste overgangen fra arkaisk kultur til aksial; men dels skal man, som jeg allerede har fremhævet, huske på, at periodiseringen er analytisk betinget (det er vi, som i lyset af vore specifikke teoretiske forudsætninger og empiriske interesser foretager den), dels at der i forhold til empirien altid er tale om analoge overgange. Det er imidlertid ikke urimeligt at betragte det sjette århundrede f.v.t. som afgørende overgangsfase i forhold til en række eurasiske kulturer fra Kina i øst, over Indien og Israel til Grækenland i vest. ${ }^{18}$ Her skete der i elitekulturen et afgørende skred, som ikke mindst var knyttet til en relativ selvstændiggørelse af en type religiøs diskurs i forhold til de fremherskende og bestående. Selvsagt var dette nybrud betinget af en række andre faktorer knyttet til socialhistorisk udvikling, demografiske, materielle og naturlige forudsætninger, som i en stadig gensidig udvikling førte til nye landvindinger.

Den amerikanske geograf Jared Diamond har i flere værker peget på væsentligheden af en række materielle, biologiske og klimatiske forudsætninger for, at det væsentligt senere aksiale gennembrud skete i en række eurasiske og fx ikke oceaniske eller amerikanske kulturer. Han har gjort opmærksom på, at netop disse kulturer i modsætning til andre havde hvede som naturlig afgrøde, tilgængelige metaller og hesten som trækdyr (1998, 132-42.157-75.361-70). Alt sammen forudsætninger for den socio-kulturelle udvikling, som man kan konstatere i aksetidskulturerne. Har man ikke mulighed for gennem naturlige afgrøder og kultivering af dem at brødføde større befolkningsgrupper, kan man glemme alt om byudvikling. Det samme gælder i forhold til andre centrale forudsætninger for en mere avanceret type landbrug. Jern var fx afgørende for opfindelsen af en mere effektiv form for plov, som igen var en forudsætning for en langt mere effektiv landsbrugsform, der skabte de materielle forudsætninger, som skulle til for tilblivelsen af større bysamfund og dermed også social stratificering. På samme måde med hesten, som af alle de 14 trækdyr, der på verdensplan lader sig domesticere, er den mest effektive - zebra og kamel er til sammenligning meget lidt anvendelige som trækdyr, og selv oksen er mindre effektiv. Vi kan da også konstatere, at en parallel udvikling skete på andre kontinenter i andre perioder, da nogle af de samme naturlige, materielle og socio-kulturelle forud-

18 Det var netop grundpointen i Karl Jaspers' forestilling om en aksetid, som - om end forudskikket hos tænkere som Abraham-Hyacinthe Anquetil-Duperron, Friedrich Hegel, Peter Ernst von Lassaulx, Friedrich Victor von Strauß og Alfred Weber - i høj grad netop er Jaspers' fortjeneste, og som Robert Bellah på meget beundringsværdig vis har videreudviklet. For problemerne i Jaspers' begreb, se min artikel 2013a. For aksetidsbegrebets historiske forudsætninger, se min artikel 2015c og Joas 2014, 8-35. 
sætninger var til stede. Det gjaldt fx de meso- og syd amerikanske kulturer som azteker og inkaer på et væsentligt senere tidspunkt. Pointen er imidlertid ikke, at der er en direkte kausal sammenhæng mellem den materielle verden og den kulturelle, som alene går fra natur til kultur. Der er i stedet tale om en høj grad af gensidighed, hvor det naturlige, materielle øver indflydelse på kultur og socialitet, ligesom det sidste øver indflydelse den anden vej.

Vender vi tilbage til den mere specifikke kulturelle udvikling, kan man konstatere tre iøjnefaldende træk. Når Robert Bellah og andre aksetidstænkere som fx Shmuel Eisenstadt sammenfattede det aksiale gennembrud, var der en række træk, som i særlig grad påkaldte sig opmærksomhed (se fx Bellah 1964; 2005; Eisenstadt 1986; 2005; 2012). Det formentlig mest afgørende punkt er spaltningen af verden i to eller flere med et dertilhørende negativt syn på den umiddelbart tilgængelige verden. En hvilken som helst form for religion vil i sagens natur operere med to eller flere verdener. Der er den kognitivt intuitivt tilgængelige verden, og så er der den anden verden, hvis aktører alene er tilgængelige gennem kontraintuitive repræsentationer. ${ }^{19}$ Denne anden verden kan yderligere opdeles i en række verdener, som man fx kender det fra middelalderens kristne kosmologier. I indfødte folks religioner og i arkaiske religioner hører guderne til i den anden verden; men de kan også tage ophold i denne verden, som når man $\mathrm{fx} \mathrm{i}$ arkaiske religioner bygger templer, om hvilke man hævder, at de er gudens bolig. Arkaiske religioner er imidlertid stærkt optaget af at vogte den ontologiske forskel mellem denne og den anden verden, så de ikke kommer i direkte berøring med hinanden. Sker det, bukker mennesket under. Tempelarkitekturen har netop til formål at opretholde balancen mellem de to verdener og sikre, at der ikke opstår utidig kontakt mellem dem. Kun en gang om året fx må ypperstepræsten $\mathrm{i}$ israelitisk religion gå ind i det allerhelligste, hvor guden bor, fordi der skal foretages en renselse eller rengøring, så guden kan vende tilbage til en ren og prydet bolig. ${ }^{20}$ Det er også kendetegnende for arkaiske religioner, at menneskene alene efter døden henlever en skyggetilværelse i Sheol eller i Hades. Der er ikke nogen tanke om udødelighed eller evighedsliv.

En sådan forestilling gøres der grundlæggende op med i de aksiale religioner. Verden opfattes som et sted, hvor mennesket ikke hører rigtigt hjemme. Som en spejling af verden forstås også menneskekroppen eller legement som fremmed bolig,

19 Begrebet kontraintuitivitet stammer fra Pascal Boyer og kognitionsvidenskaben. Det er et teknisk begreb, som ikke indebærer, at religiøs information nødvendigvis er mærkelig, uforklarlig eller specielt overraskende. Det er afgørende at være opmærksom på i forbindelse med religiøse repræsentationer, at de qua religion vil indeholde information, som er kontra-intuitiv i forhold til de kategorier, som aktiveres i de givne repræsentationer. I de monoteistiske religioner opfattes Gud fx som altseende. Det er ikke nødvendigvis mærkeligt for de religiøse udøvere; men begrebet er kontra-intuitivt i den forstand, at det indeholder information, som strider mod vor intuitive opfattelse af kategorien person, som indebærer, at man kun har information om dem, som man er sammen med og som man har været sammen med, ligesom det heller ikke indebærer en tanke om, at man kan se ind i disse personers hjertekule. For begrebet, se Boyer 2001, 65.85-87.

20 Min fremstilling bygger her ikke mindst på indsigter, jeg har fået dels gennem mangeårig diskussion med Hans Jørgen Lundager Jensen, dels gennem læsning af hans 1998-bog. 
hvor menneskets sjæl eller ånd (afhængig af, om den givne antropologi er dikotomisk eller trikotomisk tænkt) kun er på tålt ophold. Mennesket har fx i græsk og israelitisk aksial religion sit egentlige hjem i den himmelske verden, som det skal hige efter at vende tilbage til. Det gennemspilles på forskellige måder i de aksiale religioner. I platonismen $\mathrm{fx}$ er menneskets tilhørsforhold til den guddommelige verden i overvejende grad tænkt i erkendelsesmæssige og etiske kategorier knyttet til dette liv, mens en lang række jødiske former for aksialreligion lægger afgørende vægt på det fremtidige liv i den himmelske verden (se Klostergaard Petersen 2013a). Fælles imidlertid for kinesisk og græsk filosofi, indiske religiøse strømninger som buddhisme, hinduisme og jainisme, og tidlig jødedom er tanken om, at mennesket må stile efter ontologisk at forenes med sit guddommelige ophav enten i denne eller også i den anden verden. Det kræver en særlig åbenbaringsaktivitet, som kun vismanden, filosoffen, profeten eller apokalyptikeren er i stand til at bibringe menneskene.

Platons hulelignelse fra syvende bog i Staten er et godt eksempel på, hvordan problemstillingen gennemspilles i en græsk filosofisk kontekst (514-517a). I hulen sidder fanger, som har levet der, siden de var børn. De sidder dybt nede i hulen, langt fra indgangen, med både hals og ben i lænker, så de ikke kan gøre andet end at se frem for sig mod hulens bagvæg. Bag dem og uden for hulen brænder et bål. Mellem fangerne og bålet går en sti langs hvilken, der er bygget en lav mur. På den anden side af muren bevæger nogle mennesker sig med forskellige genstande. Alt hvad fangerne ser, er skyggerne fra disse ting, som reflekteres på hulens bagvæg. Den sande erkendelse finder sted, når en fange sprænger lænkerne, bevæger sig ud af hulen og begriber, at bagvæggens skygger er illusoriske. Sand væren skal ikke findes i hulen, men uden for hulen. Til gengæld kan den, som har foretaget bevægelsen ud af hulen, så vende tilbage og op-lyse de øvrige om værens sande tilstand, skønt de vil være tilbøjelige til ikke alene at latterliggøre ham, men også, hvis nogen skulle forsøge at befri dem for deres huleeksistens, pågribe ham og slå ham ihjel (517a). Sådan er ifølge Platon den aksiale figurs lod i verden. Samme tankegang findes i en række paralleller i kinesisk filosofi (Laotse, Konfutse og senere Mencius), indisk religion (upanishade-litteraturen og senere mere markant i tilblivelsen af de to ikkebrahminske retninger, buddhisme og jainisme, samt i det brede og mangesidede fænomen der sammenfattes som 'hinduisme') og i apokalyptisk tænkning i en jødisk kontekst. I den markante spaltning af denne og den anden verden finder vi det måske mest klare udtryk for forskellen på aksial og arkaisk religion.

Et andet væsentligt træk, som kendetegner det aksiale nybrud, er bevidstheden om og opgøret med konkurrerende former for kultur. I arkaiske kulturer, som fx israelitisk, finder man polemik mod andre kulturer, som fx ægyptisk som udtryk for afgudsdyrkelse og en mangelfuld religionsform. Stereotypisering og bashing af andre gruppe er en menneskelig konstant (se Klostergaard Petersen 2009 og 2012); men igen er der tale om en betydelig skærpelse, når vi retter blikket mod aksiale kultur- 
former. De bevidner ikke alene en bevidsthed om eksistensen af andre kulturer, men også et markant behov for at skulle gøre op med religiøse (inklusive filosofiske) læresystemers sandhedsprætentioner. Tanken er ikke som i arkaiske kulturer, at de andres kultur er mangelfuld sammenlignet med ens egen, men i stedet at de andres kultur er udtryk for mangelfuld indsigt, bedrag og løgn, som det demonstreres gennem ens egen kulturs sandhed, at de andre kulturer de facto repræsenterer en ikkekultur. Aksiale kulturformer har kun plads til en sandhed, og derfor må rivaliserende kulturers eller religioners fordring på sandhed afmonteres. ${ }^{21}$ Her ligger selvsagt også et element af universalisme, som kendetegner aksiale kulturers læreindhold. De er ikke stedbundne, men rækker - principielt - ud til hele verden: “Gå ud og gør alle hedninger til mine disciple, idet I døber dem i faderens, sønnens og helligåndens navn, og idet I lærer dem at holde alt det, som jeg har befalet Jer" (Matt 28, 19).

Forbundet med disse to elementer er en skærpelse af det, Merlin Donald kalder teoretisk kultur, dvs. evnen til metatænkning. En væsentlig materiel og teknisk forudsætning for det er fremkomsten af egentlige alfabetskrifter i århundrederne omkring det aksiale gennembrud, som gjorde det betydeligt lettere at kommunikere på tværs af større geografiske afstande, ligesom det også øgede muligheden for en egentlig eksternaliseret videnskultur. Det gjaldt Grækenland, Indien og Israel, men ikke Kina. Man kan se betydningen af dette inden for $\mathrm{fx}$ fremvæksten af den historiografiske litteratur, den medicinske tradition og den filosofiske diskurs. For første gang begynder man at se udviklingen af en egentlig abstrakt form for tænkning forstået som evnen til dels at formulere sig ved hjælp af andenordensbegreber, dels at kunne gøre tænkningen selv til genstand for refleksion og kritik. Der er andre ting, man også kan fremhæve i forhold til det aksiale gennembrud; men dette får være tilstrækkeligt for mit fokus her, nemlig askesen.

Med fremkomsten af de aksiale kulturer får askesen en anden karakter. Den forskydes fra den rituelle kontekst til en ideologisk defineret sammenhæng, som det ikke mindst er tydeligt i de filosofiske strømninger. Livet selv bliver et filosofisk projekt, hvor det gælder om i videst muligt omfang at ligedanne sig med den guddommelige verden, eller som Platon gennem Sokrates hævder et centralt sted i dialogen Theaitetos: “Derfor [sc.nemlig - fordi der altid vil være onde ting, som omkranser menneskene og jorden] bør vi forsøge at flygte fra jorden til gudernes bolig så hurtigt, som vi formår, for at flygte er at blive lig gud (hōmoiōsis theō), så meget som det er muligt (kata to dunaton); og at blive lig gud er at blive retfærdig og hellig gennem visdom" (176b).22 Platons betoning af 'så meget som det er muligt' er et udtryk for fastholdelsen af en ontologisk differens mellem guder og mennesker. Men-

21 Jf. Hadot, 1995b, 74: "Each philosophical or religious school or group believed itself to be in possession of a traditional truth, communicated form the beginning by the divinity to a few wise men. Each therefore laid claim to being the legitimate depositary of the truth."

22 David Sedley har i en anden sammenhæn fremhævet betydningen af imitatio-motivet hos Platon. Se Sedley 1999. Se også min 2013d-artikel og det af von Stuckrad og mig redigerede særnummer af Numen, hvor imitatio er omdrejningspunkt. Se Petersen og von Stuckrad $2013 \mathrm{f}$. 
nesker kan assimilere sig med guder; men de kan aldrig blive identiske med dem. Og som det fremgår af Platons argument, er ligedannelsen først og fremmest knyttet til et etisk register: "at blive lig gud er at blive retfærdig og hellig ved hjælp af visdom" (jf. også Klostergaard Petersen 2013b).

Hvad vi møder hos Platon, blev en yderligere pointeret central tanke i de efterfølgende post-aristoteliske eller hellenistiske filosofiske skoler, som i min forståelse alle udgjorde, hvad vi fra et etic eller tredjeordensperspektiv vil kalde religion (se hertil mine to kommende artikler $2016 \mathrm{~b}$ og c). Der er godt nok en lang tradition for at opfatte dem som væsensforskellige fra religion; men dertil er i alle fald tre ting at sige. For det første kan disse filosofiske strømningers opgør med traditionel religiøsitet ikke i sig selv tages som udtryk for en afsked med kategorien religion per se. Det bør derimod ses som et internt nybrud, hvor en form for religiøsitet polemiserer imod og afløser en anden. For det andet er det væsentligt ikke at tilbageprojicere en moderne forskel mellem filosofi og religion til den antikke verden. For det tredje er det vigtigt at åbne øjnene for elementer i de filosofiske tekster, som man ikke mindst på grund af punkt 1 og 2 i de antikke filosofiske traditioners efterfølgende normsættende virkningshistorie har været tilbøjelige til at ignorere, netop fordi de i høj lignede, hvad vi vil kalde religion (jf. Klostergaard Petersen 2016a; Klostergaard Petersen \& van Kooten 2016b).

Som Martha Nussbaum i sin eminente bog, The Therapy of Desire, har pointeret delte de tre grundlæggende post-aristotelisk filosofiske strømninger (stoicisme, skepticisme og epikuræisme - Nussbaum udelader kynismen) den overbevisning, at mennesket var sygt, og at kun filosofien kunne skænke mennesket et middel imod denne sygdom. Hun hævder også, at de sygdomme, som i særlig grad forhindrer menneskeligt velvære (eudaimonia), hidrører fra forestillinger, kulturel og social lære $(1994,34)$. Menneskelig sygdom skyldes i sidste instans manglende erkendelse. Kun filosofien kan i den sammenhæng hjælpe ved at bibringe mennesket den terapi, som er en forudsætning for overvindelsen af sygdom. Pierre Hadot, som i modsætning til Nussbaum også inddrager kynismen, har argumenteret på lignende vis, når han om de hellenistiske filosofiske strømninger samlet hævder:

Sandt at sige må man ved et første blik spørge sig selv, om opfattelserne af visdom nu også er så forskellige fra den ene skole til den anden. Samtlige hellenistiske skoler forekommer de facto mere eller mindre at definere det i samme begreber, nemlig først og fremmest som en tilstand af perfekt sjælefred. I et sådant perspektiv fremstår filosofien som en terapi for bekymringer, angst og menneskelig ulykke; for kynikerne en ulykke fremkaldt af konventioner og sociale bindinger; for epikuræerne af jagten efter falske nydelser; for stoikerne af jagten efter falsk nydelse og selvoptagethed; og for skeptikerne af falske meninger. Uanset om de gjorde krav på arven fra Sokrates eller ej, hævdede alle hellenistiske filosofier med Sokrates, at menneskene er stedt i ulykke, angst og ondskab, fordi de befinder sig i uvidenhed. Ondskaben er ikke i tingene, men i de værdidomme, menneskene fælder over tingene. Menneskene kan derfor kun behandles, når 
de forandrer deres værdidomme: alle disse filosofier ville derfor være terapeutiske. Men for at forandre sine værdidomme må mennesket foretage et radikalt valg: det må forandre hele sin tænkemåde og værensmåde. Dette valg er filosofien, og det er i kraft af det, at man kan opnå indre fred, sindsro (1995a, 161f.).

Det er netop filosofiens terapeutiske overvindelse af begær, der i Hadots optik bliver til en livsvej, une manière de vivre, eller efter min opfattelse en kontinuerlig form for ideologisk diskursiveret defineret askese. Hadot kommer selv ind på begrebet i flere centrale passager, ikke mindst når han skal beskrive, hvordan forsagelse er et afgørende element i begærsovervindelsen. I modsætning til tribale og arkaiske former for askese, hvor askesen alene optræder i rituel sammenhæng, er askesen i den aksiale kontekst blevet til en livsform, som består i daglig begærsbemestring. Det kan ske på to måder. Dels som i den tribale og arkaiske askese gennem forsagelse og privation, dels gennem træning, der i de mest ekstreme tilfælde pågår 24 timer i døgnet. ${ }^{23} \mathrm{Jeg}$ har her betinget af pladshensyn koncentreret mig om udviklingen i den græske sammenhæng, men argumentationen kan med de forskelle, som perspektivforskydningen til andre kulturkredse nødvendigvis indebærer, let overføres på tilsvarende udviklingsformer inden for kinesisk, indisk og jødisk religion.

\section{Askese som både forsagelse og træning: den aksiale askese}

Med pointeringen af bevægelsen fra den specifikt rituelt definerede til den ideologisk bestemte askese eller fra det tribalt-arkaiske til det aksialt og postaksiale kommer vi til den askeseform, som Sloterdijk i eminent grad har sans for: askese som træningsprogram. Grundlæggende betyder áskēsis på græsk 'øvelse', 'praksis' eller 'træning' . Det er derfor ikke her, baggrunden for den senere anden- og tredjeordens brug af askese som forsagelse skal søges; men derimod i den kristne 'overtagelse' af askesebegrebet, og ikke mindst i den senere traditions tilbøjelighed til med udgangspunkt i kristen askese forstået som et forsagelsesprojekt løsrevet fra askese tænkt som træning eller øvelse at indskrænke askesen til et spørgsmål om forskellige former for afkald. ${ }^{24}$

23 Jf. Hadot 2002, 290: “Den [dvs. filosofien] er en livsvej, hvilket ikke alene vil sige, at den repræsenterer en bestemt moralsk adfærd (...) men at den udgør en eksistensmodus i verden, som bør omsættes i handling i enhver sammenhæng og som bør lede til forandring af hele livet (...) Filosofien fremstår også [ud over at betegne kærlighed til visdommen] som en tanke-, vilje- og altomfattende værensøvelse med henblik på at forsøge at opnå en tilstand næsten uopnåelig for mennesket. Filosofien er en metode til opnåelse af åndeligt fremskridt, som fordrede en radikal omvendelse, en radikal forandring af ens (? livsvej (de la manière d'être)." Jf. også Hadot 2001, 159-91, særligt 159-61.

$24 \quad$ Heri ligger mit primære kritikpunkt mod Hadots i øvrigt i alle henseender fremragende og inspirerende tænkning omkring askese, nemlig at han driver en betydelig kile ind mellem den filosofiske og kristne askese. Se fx Hadot 2002, 76f: “Før vi begynder dette studie, er det godt at præcisere begrebet 'åndelig øvelse'. 'Øvelse' korresponderer på græsk til askēsis eller meletè. Det er nødvendigt, at vi først understreger og bestemmer undersøgelsens begrænsninger: Vi vil ikke tale om askese i ordets moderne betydning, sådan som det fx er defineret af K. Heussi: 'fuldstændig afholdenhed eller begrænsning i brugen af 
For at bane vej for en sådan bredere askeseforståelse, baseret på tanken om askese som træningsprogram, vil jeg illustrere det med nogle få eksempler fra hellenistiske former for filosofi, her repræsenteret ved stoikerne, som vel nok er den antikke filosofi, der mest udførligt udviklede tanken om et mentalt træningsprogram. Vi møder ikke alene askese her som særlig kultivering af sjælen, men netop som træningsprogram. På den ene side skal det gøre det muligt at kere sig om sig selv (jf. titlen på Foucault 1994) og døde begæret, og på den anden side bane vej for ligedannelsen med guden. Hos flere filosoffer kan denne proces beskrives som en tilbagevenden til det sande selv, nemlig til sjælen eller det guddommelige i mennesket (jf. Hadot 1995a, 245). Det er derfor rammende, når Hadot i en skildring af kristendom som åbenbaret filosofi fremhæver lighederne mellem kristen askese og filosofisk selvbemestring:

Opmærksomheden om selvet fører over i bemestring, selvkontrol, som man kun kan opnå gennem vane og udholdenhed i asketiske praksisser, som er bestemt til at virkeliggøre fornuftens triumf over og helst fuldstændige udryddelse af lidenskaberne. Det er i den sammenhæng nødvendigt at tage en veritabel terapi for overvindelse af lidenskaberne i anvendelse. Vejen, som fører til denne fuldstændige befrielse (apatheia), går gennem løsrivelse fra (aprospatheia) tingene, det vil sige gennem den fremadskridende fjernelse af det begær som er rettet mod ligegyldige ting (1995a, 367).

I sit 92. brev i De moralske epistler argumenterer Seneca for, at vismanden skal dyrke sit legeme med sjælens ære for øje (corpus in honorem animi coli). I sjælens styrende del er der både noget irrationelt og noget rationelt. I lighed med den guddommelige fornuft, som det rationelle hidrører fra (quia ex illa est), bør sjælen herske over det irrationelle. Legemet skal opfattes parallelt med en klædning, som naturen har omgivet sjælen med (ut quandam vestem animo circumdedit) $(92,13)$. Kroppen udgør dens dække (velamentum). Men ingen har vel nogensinde regnet tøjs værdi på baggrund af garderoben, som rummede det? Vismanden, som har dyd (virtus) og mod (animusque) i sit legemet (egtl. citat fra Æneiden 5, 363), er lig guderne (hic deos aequat) og er sig sin oprindelse bevidst $(92,29)$. Stoikeren forstår, at rigdom ikke skal søges, hvor den sædvanligvis findes. Han bør i stedet fylde sin sjæl, ikke sit pengeskab (92,

ernæring, drikke, søvn, påklædning, ejendom og helt særligt kyskhed inden for det seksuelle domæne.' Det er derfor nødvendigt, at vi sondrer omhyggeligt mellem den kristne brug, og det langt mere moderne ord askese fra brugen af udtrykket askēsis i antik filosofi. Hos antikkens filosoffer betegner udtrykket askēsis udelukkende åndelige øvelser, dvs. indre aktivitet, som hører til tanken eller viljen. Om der hos bestemte antikke filosoffer som for eksempel kynikerne og nyplatonikerne eksisterede alimentære og seksuelle adfærdsmønstre lig den kristne askese, er et andet spørgsmål. Sådanne adfærdsmønstre er forskellige fra de filosofiske tankeøvelser." Hadot er imidlertid også i stand til at inkludere dele af Kristusbevægelsen i sine overvejelser; men så er det netop de dele, der som fx de kristne apologeter konvergerer med Hadots 'græske' forståelse af askēsis. Jeg opfatter problemet som tofoldigt. For det første ser Hadot ikke forbindelsen mellem de forskellige former for askese. For det andet begriber han ikke, hvordan forskydningen i asketiske adfærdsmønstre skal ses i sammenhæng med en religionshistorisk udvikling, som ikke var specifikt knyttet til græsk filosofiske strømninger, men var del af en bredere aksial udvikling. 
31). Den sjæl, som har nået gudernes højde, er ikke en, som elsker legemet, alene en nødvendig byrde. En sådan sjæl er legemets overvåger (procurator); den underkaster sig ikke, hvad der er blevet den bemyndiget $(92,33)$. Seneca fastholder på denne måde sjæl-legeme-dualismen og dermed den ontologiske differens mellem denne og den anden verden. Samtidig understreger han meget stærkt, hvordan vismanden kan blive guddommelig gennem kultivering og træning af sjælen, som netop hidrører fra den anden verden.

Tilsvarende fortæller han i sit 41. brev Lucilius, at han gør det allerbedste og sunde, når Lucilius, som han selv har skrevet til Seneca, fortsætter med at bevæge sig frem mod et sundt sind. Han behøver hverken at løfte hænderne mod himlen eller at bede tempeltjeneren om at lede ham til gudens øre eller billede, som om han derved lettere ville blive hørt $(41,1)$. I stedet pointerer Seneca, hvordan guden er ham nær, med ham og inden i ham (prope est a te deus, tecum est, intus est) (jf. 1 Kor 3, 16; 6, 19; 2 Kor 6, 16). Lucilius skal derfor give agt på, at en hellig ånd bor i os (sacer intra nos spiritus sedet), og at den tjener som observatør og vogter af vore onde og ærefulde gerninger $(41,2)$. Ingen kan opnå status som god mand uden guden. Det er netop guden, som giver vismanden fremragende og ærlige råd. På ny er det sjælen, der forbinder vismanden med guden. Det er også den, som gennem træning kan efterligne guden og derigennem guddommeliggøres Samme tankegang finder vi hos en anden stoiker, Epiktet, som han er overleveret gennem sin student, Arrian. Helt som Seneca hævder Epiktet, at vismanden er beslægtet med guden:

Den som altså omhyggeligt har fulgt og lært om verdens indretning, at det største, mest ophøjede, mest omfattende af alle samfund (sustēma) er det, som udgøres af mennesker og Gud, og at fra ham er al sæd udgået ikke alene til min fader ej heller til farfar, men til alle, som er skabt og vokser på jorden, og i særdeleshed til de rationelle væsener, for de alene er skabt til at have fællesskab med Gud ved gennem fornuften at være forbundet (kata ton logon epi peplegmena) (med ham) - hvorfor skulle en sådan mand ikke kalde sig selv verdensborger (dia ti mé eipé tis auton kosmion)? Hvorfor ikke en søn af Gud (dia ti mē huion tou theou)? (I 9, 4-6).

Også Epiktet forfægter synspunktet, at mennesket i kraft af delagtigheden i den guddommelige fornuft er beslægtet med guden. Hvor radikal denne status bør tænkes, fremgår af en række andre passager, hvor Epiktet ikke alene betoner nødvendigheden af at følge gudens kald (se fx I 9, 24f; og Enchiridion 7), men også imitationsmotivet, som består i en særlig træning eller sjælekultivering. Når menneske har lært, at der er en gud, og at han sørger for menneskene, må de fortsætte til selve ligedannelsen med guden:

Dernæst (underforstået: må vi lære), hvordan guderne er. For sådan som de forekommer at være, er det nødvendigt, at han, som søger at behage og adlyde dem, efter evne må forsøge at ligne dem (peirasthai kata dunamin exhomoiousthai ekeinois). Hvis guddommen er trofast, må også han være trofast; hvis fri, må han også være fri; hvis godgøren- 
de, må også han være godgørende; hvis storsindet, må også han være storsindet: han må altså i alt, hvad han gør og siger, være en efterstræber af guden (hōs theou toinun zēlōtēn) (II 14, 12f.).

Svarende til Senecas filosof og Kristustilhængeren hos Paulus har Epiktets vismand sprængt den ontologiske grænse mellem det guddommelige og det menneskelige. Det har han gjort gennem et træningsprogram, som bestandigt opøver ham i at efterligne guddommen for at blive som den. Det sker gennem træning og dyrkelse af sjælen, og forsagelsen er her et væsentligt element i træningsprogrammet, men bestemt ikke det eneste. Et sidste eksempel kommer fra yderligere en stoiker, filosofkejseren Marcus Aurelius. I den anden bog af sine Meditationer konstaterer Marcus, at menneskets livslængde er et punkt, hvis beståen (ousia) flyder bort. Erkendelsen af det er vanskelig. Hele kroppens sammensætning er let forrådnelig og sjælen en hvirvel, skæbnen uforudsigelig og berømmelse usikker. Ja, alt, hvad der hører legemet til, er som en flod og sjælen blot en drøm og bedrag (II 17). I den situation er der kun et at gøre, at ty til filosofien: “Og den består i at holde den indre guddom fri for fornærmelse og skadesløs" (jf. II 13; III 2; IV 1). Den stoiske vismand er netop: "en sådan, som ikke excellerer i allerede at være blandt de bedste, men snarere er som en præst og gudetjener, der benytter det, som er placeret inden i ham, til at holde mennesket uplettet for lyster, usårlig over for al smerte, urørt af enhver overtrædelse, ufølsom over for al smerte, atlet i den allerstørste kamp (athlētēn athlou tou megistou), nemlig ikke at slås ned af nogen lidenskab..." (III 3). Det er i det hele taget et gennemgående billede, at atletmetaforikken bruges om filosoffen, ligesom det bruges i den tidlige Kristusbevægelse og hos Paulus især om Kristustilhængeren. ${ }^{25}$ Jeg vil fremdrage et sidste teksteksempel, som gør sammenhængen mellem askese, træning og filosofi som sjælekultivering fuldstændig klar. Marcus Aurelius fortæller i indledningen til den fjerde bog, hvordan mænd søger fristeder (anachōrēseis) på landet, ved havet og i bjergene; men det er aldeles egensindigt (idiōtikōtaton), når man har mulighed for at søge fristed hos sig selv (eis heauton anachōrein): "For intet andet sted kan mennesket finde et mere stille og handlingsfrit fristed end i sin sjæl." Mennesket skal netop bruge dette fristed og forny sig selv (IV 1).

Jeg har her valgt at fremhæve tekster, som primært vægter vismandens stadige imitation af guddommen knyttet til opøvelsen i en bestemt indstilling til verden, som filosoffen må lægge sig på sinde for i stadig større grad at gøre det til sin kognitive habitus, som så også slår om i handling for at kulminere i vismandens fremadrettede bevægelse mod at blive en gud-lig. (Samme tanke gennemstrømmer i øvrigt i endnu mere bombastisk forstand den tidlige Kristus-bevægelse). Som vi har set i disse få stoiske tekster, indgår forsagelse og træning forstået som opøvelse i en bestemt måde at tænke verden på med en dertilhørende adfærd som helt centrale elementer. Forsa-

25 Jf. fx Seneca Ep. 78, 16; Epiktet Ench. 51; Diatr. I 18.20-23; II 8; III 23.2-5; 1 Kor 9, 24-27; Fil 3, 12-14; Filon Migr. 27; 200; Mut. 81f.; 88; Somn. 130-32. Se yderligere Pfitzner 1967; Poplutz 2006; Brändl 2006; Arnold 2014. 
gelsesaspektet kender vi allerede fra den tribale og arkaiske sammenhæng; men her har det fået ny betydning. Forsagelsen er ikke længere rituelt, men ideologisk bestemt. Den gælder ikke primært rituel afholdenhed, men derimod askese i forhold til begær og lidenskab, som må bekæmpes, tæmmes og bemestres. Tilsvarende er træningsperspektivet nyt. Det peger, som vi skal se, frem mod modernitetens askeseformer, fra coaching og fitness til ironman og selvterapi; men før vi når dertil, vil jeg kort overveje privationsaspektet, som ikke er særlig fremtrædende i de filosofiske askeseformer. Eller rettere det har fået ny betydning.

\section{Fra det transitive til det refleksive offer: det asketiske primat i kulturhistorien}

Jeg understregede tidligere, hvordan man hos Durkheim og med ham den senere tænkning omkring askese savner sans for forskellen mellem forsagelses- og privationsaspektet. Privationselementet får imidlertid en ny betydning i den aksiale sammenhæng. Hvor privationen i en tribal og arkaisk kontekst finder sted i rituel sammenhæng, forskydes det i aksialreligionerne til en ideologisk defineret form for privation i forbindelse med træningsprogrammet; men her indtræffer samtidig en anden væsentlig religionshistorisk bevægelse, som imidlertid er meget logisk i lyset af drøftelsen i det forudgående afsnit. Det klassiske offer er transitivt og hører hjemme i sammenhæng med templet: 'Jeg giver noget på vegne af mig selv som tak for, hvad jeg har modtaget, hvorved jeg også stadfæster forholdet til guden/erne og gør mit til, at jeg også fortsat kan modtage velsignelser fra dem.' Er afstanden mellem guddommelig og menneskelig verden imidlertid blevet så betydelig, at verden i almindelighed forstås i et diametralt modsætningsforhold til den guddommelige sfære, kan mennesket ikke længere gennem ofre give guden af verdens velsignelser, eftersom de nu repræsenterer en gudsfjendtlig verden. Mennesket kan derfor kun give, hvad der hidrører fra den guddommelige verden selv. Det bliver mennesket selv i skikkelse af den sjæl eller ånd, som forløst fra kødet kan vende tilbage til sit guddommelige ophav eller til den verden, hvor det sande menneske hjemhører. Et sådant offer er ikke længere transitivt, men derimod refleksivt. Mennesket giver sig selv til guden og udtrykker derigennem fortsat privationselementet: 'Jeg har mit liv, fordi jeg har fået det skænket.' Det sker løbende gennem de forskellige former for træningsprogrammer, hvor dødelse af lidenskaber og begær står i centrum. Man kan fx tænke på Paulus' Romerbrev 12, 1-2, hvor forskydningen udtrykkes meget klart: "Jeg tilskynder Jer altså brødre gennem Guds barmhjertighed til at fremstille Jeres legemer som et levende, helligt og velbehageligt offer for Gud, Jeres fornuftige gudstjeneste. Og I må ikke skikke Jer lig denne æon, men I skal gennem sindets fornyelse lade Jer forvandle, så I kan prøve, hvad der er Guds vilje, det gode, velbehagelige og fuldkomne." Som vi har set i de tidligere teksteksempler, kan stoikeren - og andre filosoffer føjer jeg til - formulere sig meget lig Paulus. 
Skruer man yderligere op for volumen i denne bevægelse fra det transitive til det refleksive offer, når man som den mest excessive form for refleksivt offer martyriet, som i særlig grad forbindes med Kristusreligionen fra midten af det andet århundrede og frem. Men tanken om den ædle død er bestemt ikke enestående for Kristusbevægelsen (se fx i anden jødisk sammenhæng 2 og 4 Makk; jf. Klostergaard Petersen 2007). Der er igen tale om et grundlæggende aksialt element, som finder forskellige udtryk i de utallige manifestationer af aksialreligionerne (se fx for en græsk-romersk og jødisk sammenhæng Droge \& Tabor 1992; Sterling 2001). På ny mener jeg, der er en pointe $\mathrm{i}$ at holde dette aspekt specifikt adskilt fra forsagelseselementet som sådan. Privationsdimensionen er ikke alene en yderligere skærpelse, men indgår også i en meget klar indeksikal markering af tilhørsforholdet til guddommen, selvsagt mest emfatisk udtrykt i det bogstavelige martyrium, hvor martyren giver sin sjæl til guden og netop og ikke til verden og dens herskere. De overlades det kød, som i forvejen er bestemt til forrådnelse og tilintetgørelse.

Martyriet er naturligvis en meget bastant form for refleksivt offer; men min påstand er, at samme tanke bringes i anvendelse på askesen forstået som træningsprogram. Det liv, der skal ændres, skal forandres gennem ligedannelse og guddommeliggørelse, så mennesket aflægger sig sit jordiske legeme for at blive guddommen lig. De forudgående stoiske tekster og de få eksempler, jeg har fremdraget fra Paulus, har vist, hvordan denne udviklingstanke integreres i forestillingen om livet som et langt træningsprogram, som den enkelte selv må virkeliggøre. Her ligger også en ny forståelse af selvet, måske ikke kimen til moderne individualisering, men i alle fald en betydelig mere prægnant pointering af mennesket som et selv (se Klostergaard Petersen 2013c). De fysiske privationer som fx omskærelse, tandudslåen, afbarbering af hår, etc. viger til fordel for en mere grundlæggende privation, hvor man aktivt giver sig selv hen til en træning målrettet mod at blive som træneren, dvs. guddommen. Derved får privationen også ny betydning, fordi man er gået fra en privation, hvor man selv er objekt for andres handlen, til en aktiv privation, hvor man selv er blevet subjekt for en livslang selvudslettelse frem mod det endelige mål at blive gud-lig. Gennem sjæl eller ånd har man allerede fået lod og del i guddommen; men gennem den fortsatte træningsindsats, der negativt består i stigende afstandtagen fra verden og positivt i øget ligedannelse med guden, er man slået ind på den vej, som ultimativt fører til indoptagelsen i den guddommelige verden. Her når det refleksive offer sin kulmination.

$\mathrm{Nu}$ vil en og anden måske indvende, at mange af de ting, jeg her har talt om, jo netop genopstår i senere former for aksialreligioner, det gælder fx brugen af tonsur i kristne munkeordener, omskærelse i islam, offerforestillinger i det femte og sjette århundreders kristne nadverteologi, etc. Det er rigtigt; men det er just også grunden til at betone forskellen mellem aksiale og post-aksiale religionsformer, hvor de sidste fremstår som et kompromis mellem det arkaiske og det aksiale gennem reintroduktionen af mange arkaiske elementer i den aksiale sammenhæng. Det sker fx i jødedom 
og kristendom i det femte og sjette århundrede, ligesom det giver god mening at se islam som repræsentant ikke for en aksial, men derimod en postaksial religionstype. Men hvad nu med den videre udvikling frem til de moderne askeseformer?

\section{Fra aksialiteten frem mod moderniteten: Træningsprogrammerne løsrevet privationsaspektet}

Som jeg tidligere har gjort opmærksom på, må jeg af pladsgrunde her se bort fra bevægelsen fra den aksiale til den post-aksiale askeseform. Den er da heller ikke helt så iøjnefaldende som det spring, der indtræffer med forskydningen fra det aksiale og postaksiale til moderniteten. Der er i den sammenhæng to punkter, som det i særlig grad er værd at hæfte sig ved. Det første punkt er Oplysningstiden og løsrivelsen fra en religiøst bestemt ideologisk ramme for askesen. Dermed forsvinder privationsaspektet som del af askesen, eftersom der ikke længere er nogen guddom at ofre sig til. Var den asketiske privation fra tribalkulturer og frem gennem arkaiske, aksiale og post-aksiale kulturer frem til moderniteten et indeksikalt udtryk for tilhørsforholdet til den anden verden, måtte netop dette element forsvinde fra det tidspunkt, hvor mennesket åndshistorisk tog afsked med forestillingen om at være det guddommeliges ejendom. Nu ved jeg selvsagt godt, at modernitet og Oplysningstid er andet og mere end religionskritik og sekularitet. Langt de fleste former for Oplysning var, som ikke mindst Roy Porter og Gertrude Himmelfarb i en række værker har dokumenteret, grundlæggende et religiøst bestemt forsøg på at befri religion og kristendom især for, hvad man opfattede som dens overtroiske og irrationelle træk, kort sagt dens tåbeligheder (fx Porter 2001; Himmelfarb 2008). Det ændrer dog ikke ved, at der navnlig i dele af den franske oplysningstænkning og eksklusivt i den skotske blev sat en ny dagsorden, som ad åre førte til, at privationsaspektet helt og aldeles forsvandt. Når guden forsvinder, går også det privationsaspekt tabt, hvis raison d'êtré netop var stadfæstelsen af den kontraktuelle tjeners asymmetriske og underordnede forhold til guden.

Det andet væsentlige punkt, som kendetegner askesen i moderniteten, er romantikken og dens demokratiserende tanke om, at hver og en er kaldet til at virkeliggøre sit særlige træningsprogram. I og for sig kan man hævde, at denne forestilling ligger i direkte forlængelse af aksialitetens imperativ: "Du mußt dein Leben ändern;" men det nye her består i den asketiske demokratisering eller vulgarisering, om man vil. Billedlig talt er det Caspar David Friedrichs ensomme vandringsmand, som forlader lærredet, og som hver og en af os kaldes til at legemliggøre. Goethe, Schiller, Hölderlin, Friedrich, Schubert, Wagner, etc. havde næppe forestillet sig senmodernitetens konsekvenser af det asketiske imperativ: pilgrimsvandringer, fitnesscentre, coachingkulturen, ironmandriften til bestandigt at højne barren, stadigt at bevæge sig højere op ad det Mount Improbable, som Sloterdijk i forlængelse af Dawkins betegner driften mod de olympiske idealer omsat i det almindelige menneskes eller mas- 
sens higen mod at gøre netop sit træningsprogram bestemt af altius, citius, fortius: højere, hurtigere, stærkere. Altid på vej frem- eller opad, aldrig i hvile på det bjerg, hvis tinde opløftes mod nye højder.

Det er der imidlertid ikke noget overraskende i. Demokratiseringsprocessen, godt bistået af og selv et væsentligt led i en meget omfattende teknologisk udvikling, har muliggjort denne udbredelse af aksialitetens elitære formaning til vismanden om at leve sit liv i gudens tjeneste og derigennem forme sig til en gud-lig til i stedet for at handle om legemsdyrkelse og åndskultivering: “Du mußt dein Leben ändern." Dermed kan vi så også iagttage en anden helt afgørende forskydning. Askesen hører ikke længere primært hjemme i, hvad vi fra et etic perspektiv må opfatte som religion sensu stricto. Den har som Friedrichs vandringsmand forladt sin ramme og har søgt mod nye steder og nye rum: Altid på lettende vinge... (med behørig hilsen til den norske digter Bull). Lindetræet har som hos Schubert afløst guden; men kaldet er fortsat det samme og formaningen til den enkelte om forandre sit liv til en stadig indøvelse i den ideale væren og gøren, som træningen stræber frem mod virkeliggørelsen af: “Nun bin ich manche Stunde Entfernt von jenem Ort, Und immer hör' ich's rauschen: Du fändest Ruhe dort" (se Klostergaard Petersen 2005, 421-25).

\section{En kort konklusion}

Jeg har her vovet et øje og skitseret en genealogisk funderet typologi til kortlægning af askese som et universelt fænomen. Det har været det primære mål med dette essay. Det har jeg gjort i forlængelse af Durkheims tanke om askesen som indbegreb af den negative kult. Over for en traditionel askeseforskning, der alene har set fænomenet i sammenhæng med en kristen-jødisk og indisk religionshistorisk kontekst, har jeg påpeget nødvendigheden af at sammentænke et sådant askesebegreb med ikke mindst antropologiens traditionelle forståelse for askesens forekomst i rituel sammenhæng. I forlængelse af dels Peter Sloterdijk tanke om askese som en formaning til at forandre sit liv, dels Pierre Hadots fremhævelse af græsk-romersk áskēsis som en livsvej har jeg understreget nødvendigheden af et betydeligt bredere askesebegreb, som i mindre grad vægter en teistisk religionsforståelse, men i højere grad lægger sig i forlængelse af en durkheimsk religionsdefinition, hvor religion tænkes som menneskets dyrkelse af dets egne højeste værdier, hvad det regner for helligt eller med Roy Rappaport dets USP'er, dvs. ultimate sacred postulates. En sådan bredere tilgang har, håber jeg, givet mig mulighed for for det første at vise fænomenets mangfoldighed og for det andet at forklare, hvordan forskydninger og større bevægelser må ses som resultat af mere grundlæggende socio-kulturelle forandringsprocesser. Dermed har skitseringen af askesens historie fra tribale frem til moderne samfund også tjent til at vise brugbarheden og overbevisningskraften i et (bio)kulturevolutionært perspektiv, som jeg her primært har bragt i anvendelse i forlængelse af Merlin Donalds og Robert Bellahs evolutionære teorier. Derved håber jeg at have dokumenteret, hvordan 
det aksiales gennembrud fra omkring det sjette århundrede f.v.t. og frem gennem de efterfølgende århundreder samt modernitetens fremkomst omkring det 19. århundredes begyndelse har været de to helt afgørende punkter for en forandring af askesens væsen og udseende.

Endelig vil jeg godt konkluderende gentage de fire, indbyrdes relaterede punkter, som har været omdrejningspunkt for mine overvejelser: 1) ønsket om at etablere en genealogisk funderet askesetypologi, som på tværs af tid og rum indfanger fænomenet i dets bredde; 2) forsøget på at sammentænke to ikke umiddelbart forenelige askesebegreber, nemlig askese som hhv. forsagelse eller afkald og som i ordets etymologiske betydning træning eller øvelse; 3) en uddybning af skelnen mellem det transitive og det refleksive offer, som samtidig sætter mig i stand til at sondre mellem askese som forsagelse og som privation; 4) et ønske om at kaste et grundlæggende komparativt lys på askese. I forhold til de fire punkter optræder punkt 1 og 4 som gennemgående pointer og mål med artiklen, mens punkt 2 og 3 er delemål. Til gengæld er det netop dem, som belyser de to helt afgørende overgange, som jeg i det forudgående afsnit har fremhævet som særligt betydningsfulde for en forståelse af askesens historie. De to forskellige askeseopfattelser under punkt 2 skal ses i sammenhæng med bevægelsen fra tribalt-arkaiske til aksiale og efterfølgende religionsformer. Mens de første er rituelt definerede, er de sidste ideologisk bestemte. Forskydningen fra den rituelt determinerede til den ideologisk fastlagte askese modsvarer netop udvidelsen i askesebegrebet til ikke kun at rumme forskellige former for forsagelse, men også en opfattelse af askese (áskēsis) som træningsprogram. Denne forandring modsvarer den under punkt 3 berørte bevægelse fra transitivt til refleksivt offer. Ofre som dyr eller afgrøder på vegne af én selv erstattes af det mere omfattende refleksive offer: $D u$ mußt dich selbst opfern som led i ligedannelsen med den guddommelige verden. Dette element forsvinder imidlertid med moderniteten, hvor kun askesen som øvelse lades tilbage.

\section{LITTERATUR}

Arnold, Bradley

2014 Christ as the Telos of Life. Moral Philosophy, Athletic Imagery, and the Aim of Philippians, Mohr-Siebeck.

Bellah, Robert N.

1964 "Religious Evolution", American Sociological Review 29 (3), 358-374.

2005 "What Is Axial about the Axial Age?", European Journal of Sociology 46 (1), 69-89.

2011a Religion in Human Evolution: From the Paleolithic to the Axial Age, Harvard University Press.

2011 b "Nothing is ever lost: an interview with Robert Bellah, The Immanent Frame. Secularism, religion, and the public sphere", http://.ssrc.org/tif/2011/09/14/nothing-is-ever-lost/ 2011 (set 20.08.15).

2012 Robert N. Bellah og Hans Joas, eds., The Axial Age and Its Consequences, Harvard University Press.

Boyer, Pascal

2001 Religion Explained. The Evolutionary Origins of Religious Thought, Basic Books.

Brändl, Martin

2006 Der Agon bei Paulus: Herkunft und Profil paulinischer Agonmetaphorik, Mohr-Siebeck. 
Brown, Peter

1988 The Body and Society. Men, Women, and Sexual Renunciation in Early Christianity, Columbia University Press.

Descola, Philippe,

1996 "Constructing natures: Symbolic ecology and social practice", in: Philippe Descola \& Gísli Pálsson, eds., Nature and society: Anthropological perspectives, Routledge, London/New York, 82-102.

2005 Par-dèla nature et culture, Gallimard.

Diamond, Jared

1998 Guns, Germs, and Steel. A Short History of Everybody for the last 13,000 Years, Vintage.

Donald, Merlin

2001 A Mind so Rare. The Evolution of Human Consciousness, W.W. Norton.

2006 "Art and Cognitive Evolution", in: Mark Turner, ed., The Artful Mind. Cognitive Science and the Riddle of Human Creativity, Oxford University Press, 3-20.

Droge, Arthur \& George Tabor

1992 A Noble Death: Suicide and Martyrdom among Christians and Jews in Antiquity, Harper Collins.

Durkheim, Émile

2007 Les Formes élémentaires de la vie religieuse, CNRS.

Eisenstadt, Shmuel N.

1986 "Introduction. The Axial Age Breakthroughs-Their Characteristics and Origins", in: idem, The Origins and Diversity of Axial Age Civilizations, State University of New York Press.

2012 "The Axial Conundrum between Transcendental Visions and Vicissitudes of Their Institutionalizations. Constructive and Destructive Possibilities", in: Robert N. Bellah \& Hans Joas, eds., The Axial Age and Its Consequences, Harvard University Press, 278-293.

Eisenstadt, Shmuel N. \& Johann P. Arnason, eds.,

2005 Axial Civilizations and World History, Brill.

Flood, Gavin

2004 The Ascetic Self. Subjectivity, Memory and Tradition, Cambridge University Press.

Foucault, Michel

1994 Histoire de la sexualité, tome trois. Le souci de soi, Gallimard.

Freiberger, Oliver, ed.

2006 Asceticism and Its Critics. Historical Accounts and Comparative Perspectives, Oxford University Press.

Hadot, Pierre,

1995a Qu'est-ce que la philosophie antique?, Galimard, Paris.

1995b Philosophy as a Way of Life, Blackwell.

2001 La philosophie comme manière de vivre. Entretiens avec Jeannie Carlier et Arnold I. Davidson, Albin Michel.

2002 Exercises spirituels et philosophie antique, Albin Michel.

Halbmayer, Ernst,

2012 "Debating Animism, Perspectivism and the Construction of Ontologies", Indiana 29, 9-23.

Himmelfarb, Gertrude

2008 The Roads to Modernity: The British, French and American Enlightenments, Vintage Books.

Hubert, Henri og Mauss, Marcel

1899 Essai sur la nature et la fonction du sacrifice, Mélanges d'histoire des religions, Librairie Félix Alcan.

Lundager Jensen, Hans Jørgen

1998 Gammeltestamentlig religion, Anis.

2013 "Udstigere og immunsystemer, asketer og akrobater: om Peter Sloterdijks “Du mußt dein Leben ändern. Über Anthropotechnik", Religionsvidenskabeligt Tidsskrift 60, 75-97.

Joas, Hans,

2014 Was ist die Achsenzeit? Eine wissenschaftliche Debatte als Diskurs über Transzendenz, Schwabe Verlag. 
Klostergaard Petersen, Anders

1996 "Ritologien - et forsømt teologisk område", Dansk Teologisk Tidsskrift 1, 1-26.

2004 "Ritualet som betydningsstabiliserende faktor - mellem symbolicitet og indeksikalitet", in: Mette Birkedal Bruun og Kim Esmark, eds., Ritualer i kontekst. Kirkehistoriske fragmenter, vol. 2, Det Teologiske Fakultet, 1-24.

2005 "Religiøs modenhed eller Sancho Pancha til hest", Psyke E Logos 26 (2), 543-558.

2009 "Barbarernes betydning - en studie i grænsedragning og konstruktion af fjendebilleder", Religion. Tidsskriftet for Religionslærerforeningen for Gymnasiet og HF 3, 48-57.

2011a "Påtvungen gavmildhed i 2 Korintherbrev: Udveksling og kontraktuel tænkning som bærende struktur hos Paulus", Dansk Teologisk Tidsskrift 1, 43-58.

2011b "Rituals of Purification, Rituals of Initiation: Phenomenological, Taxonomical, and Cultural Evolutionary Reflections", in: David Hellholm, Tor Vegge, Eivind Nordeval \& Krister Hellholm, eds., Ablution, Initiation, and Baptism, vol. I, De Gruyter, 3-40.

2012 "Othering in Paul: a Case-Study of 2 Corinthians", in: Maijastina Kahlos, ed., The Faces of the Other: Religious Rivalry and Ethnic Encounters in the Later Roman Period, Brepols, 19-50.

2013a "Aksetid, det aksiale, aksialisering", Religionsvidenskabeligt Tidsskrift 60, 57-74

2013b "Justin Martyr in Search of the Self", in: Jörg Rüpke \& Greg Woolf, eds., Religious Dimensions of the Self in the Second Century CE, Mohr-Siebeck, 104-129.

2013c "Finding a Basis for Interpreting New Testament Ethos from a Greco-Roman Philosophical Perspective", in: Jan Willem van Henten \& Joseph Verheyden, eds., Early Christian Ethics in Interaction with Jewish and Greco-Roman Contexts, Brill.

2013d “Attaining Divine Perfection through Different Forms of Imitation", Numen LX (1), 7-38.

2013e "Paul and Magic. Complementary or Incongruent Entitities? An Essay on the Scholarly Use of the Concept of Magic, Its Definition, and the Prevalence of the Phenomenon in Paul's World", in: Hellen Jacobus, Anne de Hemmer Gudme \& Phillipe Guillaume, eds., Studies on Magic and Divination in the Biblical World, Gorgia Press.

2015a "Zur Zeit wird hier das Raum: a Cultural Evolutionary Perspective on Paul and His Religion as Epitomised by His Letters," in: Gerald van den Heever, ed., Spatialising Practices, Brill (under udgivelse).

2015b "1 Maccabees from an Axial Age Perspective", in: Michael Tilly, Stefan Krauter \& Predrag Bukovec, eds., Die Makkabäer/The Maccabees. Festschrift for Professor Hermann Lichtenberger, Mohr-Siebeck (under udgivelse).

2015c "Eskatologi - et aksialt fænomen. Eskatologi, messianologi og apokalyptik", in: Thomas Arentzen, ed., Tid och Evighet. Eskatologi i den tidliga kyrkan, Artos og Norma Bokförlag (under udgivelse).

2016a "Philosophy and Religion and Their Interactions in the Ancient Graeco-Roman World: 4 Maccabees as an Epitome of Religio-Philosophical Axiality", in: George van Kooten \& Anders Klostergaard Petersen, eds., Philosophy and Religion and Their Interactions in the Ancient Graeco-Roman World, Brill (under udgivelse)

2016b "Cultural Evolution, Axial Age and the Formation of Early Christianity", in: Jesús Peláez, Dámaris Romero \& Israel Muñoz Gallarte, eds., Festschrift to Antonio Piñero, El Almendro.

Klostergaard Petersen, Anders \& Kocku von Stuckrad

2013f "The Gods as Role Models in Western Traditions: Introduction to the Special Issue", Numen LX (1), 1-6.

Klostergaard Petersen, Anders \& George van Kooten

2016c "Introduction to Philosophy and Religion and Their Interactions in the Ancient Graeco-Roman World", in: George van Kooten og Anders Klostergaard Petersen, eds., Philosophy and Religion and Their Interactions in the Ancient Graeco-Roman World, Brill (under udgivelse).

Kozybski, Alfred

2000 "Supplement III. A Non-Aristotelian System and Its Necessity for Rigour in Mathematics and Physics", in: idem, Science and Sanity. An Introduction to Non-Aristotelian Systems and General Semantics, 5th edition, Institute of General Semantics, 741-761.

Nussbaum, Martha

1994 The Therapy of Desire. Theory and Practice in Hellenistic Ethics, Princeton University Press. 
Pfitzner, Victor

1967 Paul and the Agon Motif. Traditional Athletic Imagery in the Pauline Literature, Brill.

Poplutz, Uta

2006 Athlet des Evangeliums: Eine motivgeschichtliche Studie zur Wettkampsmetaphorik bei Paulus, Herder.

Porter, Roy

2001 The Enlightenment, Palgrave Macmillan.

Sedley, David

1999 "The Ideal of Godlikeness", in: Gail Fine, ed., Plato 2: Ethics, Politics, Religion, and the Soul, Oxford University Press, 309-328.

Sloterdijk, Peter

2009 Du mußt dein Leben ändern. Über Anthropotechnik, Suhrkamp.

Smith, Jonathan Z.

1978 Map Is not Territory. Studies in the History of Religions, Brill.

Sterling, Greg

2001 "Mors philosophi: The Death of Jesus in Luke", Harvard Theological Review 94 (4), 383-402.

Turner, Victor

1969 Structure and Anti-Structure. The Ritual Process, Aldine.

Viveiros de Castro, Eduardo B

1998 "Cosmological deixis and Amerindian perspectivism", Journal of the Royal Anthropological Institute (N.S.) 4 (3), 469-488.

Weber, Max

1963 Gesammelte Aufsätze zur Religionssoziologie, vol. I, Mohr-Siebeck.

Wimbush, Vincent \& Valantasis, Richard

1995 Asceticism, Oxford University Press.

Anders Klostergaard Petersen, professor MSO, cand.theol. Afdeling for Religionsvidenskab, Institut for Kultur og Samfund, Aarhus Universitet 